\title{
Plant Platforms for Efficient Heterologous Protein Production
}

\author{
Siddhesh B. Ghag, Vinayak S. Adki, Thumballi R. Ganapathi, and Vishwas A. Bapat
}

Received: 7 December 2020 / Revised: 14 January 2021 / Accepted: 16 January 2021

(C) The Korean Society for Biotechnology and Bioengineering and Springer 2021

\begin{abstract}
Production of recombinant proteins is primarily established in cultures of mammalian, insect and bacterial cells. Concurrently, concept of using plants to produce high-value pharmaceuticals such as vaccines, antibodies, and dietary proteins have received worldwide attention. Newer technologies for plant transformation such as plastid engineering, agroinfiltration, magnifection, and deconstructed viral vectors have been used to enhance the protein production in plants along with the inherent advantage of speed, scale, and cost of production in plant systems. Production of therapeutic proteins in plants has now a more pragmatic approach when several plant-produced vaccines and antibodies successfully completed Phase I clinical trials in humans and were further scheduled for regulatory approvals to manufacture clinical grade products on a large scale which are safe, efficacious, and meet the quality standards. The main thrust of this review is to summarize the data accumulated over the last two decades and recent development and achievements of the plant derived
\end{abstract}

Siddhesh B. Ghag*

School of Biological Sciences, UM-DAE Centre for Excellence in Basic Sciences, University of Mumbai campus, Kalina, Santacruz, Mumbai 400098, India

Tel: +91-9619821702; Fax: +91-22-26532134

E-mail: siddhesh.ghag@cbs.ac.in

Vinayak S. Adki

V. G. Shivdare College of Arts, Commerce and Science, Solapur, Maharashtra 413004, India

Thumballi R. Ganapathi*

Plant Cell Culture Technology Section, Nuclear Agriculture \& Biotechnology Division, Bhabha Atomic Research Centre, Trombay, Mumbai 400085, India

Tel: +91-22-25593276; Fax: +91-22-25505151

E-mail:trgana@barc.gov.in

Vishwas A. Bapat

Department of Biotechnology, Shivaji University, Vidyanagar, Kolhapur, Maharashtra 416004, India therapeutics. It also attempts to discuss different strategies employed to increase the production so as to make plants more competitive with the established production systems in this industry.

Keywords: biopharmaceuticals, clinical trials, magnifection, protein, plantibodies, vaccines, therapeutics

\section{Introduction}

Protein synthesis is a very complex process, which involves translation of mRNA on ribosomes and post-translational modifications of protein (glycosylation, phosphorylation, and proper folding), required for its stability and precise expression of its biological activity. Being a tightly regulated process, protein synthesis involves sequential activities of enzymes and co-factors at various steps and also linked to other physiological and biochemical factors. Production of a protein outside its natural host system is called heterologous protein production [1,2] and has been extensively reported in yeast and in other microbes [3]. Simultaneously many other non proteinous biomolecules have also been expressed in microbes $[4,5]$. Heterologous proteins are divided into three major groups: therapeutic proteins (for pharmaceutical use, [6,7]), reagent proteins (for research and study purposes), and industrial proteins (for various industrial applications, [8]). Among these, proteins used as biopharmaceuticals and for therapeutic purposes form an extraordinary class with the stringent quality standards demanding high value [9]. Recently, an Arabidopsis-based super-expression system, was developed and used for a structural pilot study of a multi-subunit integral membrane protein complex [10]. Today, the share of biopharmaceuticals is $28.7 \%$ of the total global pharmaceutical industry. The opportunities in biopharmaceuticals are growing very rapidly with an 
expected increase from US\$ 200 billion in 2013 to US\$ 500 billion in the year 2020. There are at present approx. 2500 biotech drugs in discovery phase and 1500 biopharmaceuticals undergoing clinical trials [11,12] (http:// www.marketresearchstore.com/report/globalbiopharmaceuticals-industry-2015-market-growth-trendsand-45928).

Bacterial [13], fungal [14,15], plant [16], and animal systems $[17,18]$ have been used since 1970 s to produce a variety of recombinant proteins and later explored to produce biopharmaceuticals in addition to industrially relevant proteins. Escherichia coli was the pioneer expression system in which first therapeutic protein, somatostatin, was successfully expressed [13]. Insulin was the first FDA approved therapeutic protein produced from E. coli expression system [19]. ATryn was first approved as a therapeutic protein produced from transgenic animal (http:// www.transgenics.com/products/atryn.html). The first examples, reported in 1990, of heterologous protein production using transgenic plant cell suspension culture is a recombinant human serum albumin [16] and chloramphenicol acetyltransferase [20].

However, it is challenging to meet the high-volume demand of heterologous proteins by all those systems because of limitations of cost, cumbersome procedures, and problems in upscale. Production costs are the key issue for recombinant protein production in non-plant sources, and several factors contribute for higher costs. In view of these factors, efficiency of plant cell suspensions cultures of bamboo was employed for the production of exogenous secondary metabolites [21]. Nevertheless, plants offer remarkable platform for large scale production of eukaryotic proteins and are found to be safe, reasonably cheap, and efficacious. The upfront cost of generating recombinant plant material includes standardization of the experimental protocols, cost of growing, harvesting plant material, and the downstream processing and purification cost. Improvement in expression of heterologous protein at cellular and molecular level is one of the practical ways to alleviate these limitations [22]. Goulet et al. [23] emphasized the relevance of both considering main stem leaves and axillary stem leaves while modeling heterologous protein production in Nicotiana benthamiana. Moreover, they highlighted the potential of exogenously applied growthpromoting hormones to modulate host plant architecture for improvement of protein yields. An ideal expression system should possess (i) capability to produce the required protein with right conformation, (ii) good productivity, (iii) easy handling and maintenance, (iv) safe and economic, (v) affordable downstream processing, and (vi) easy amenability for experimental manipulations.

\section{Plants as Expression Systems: Advantages and Disadvantages}

Microbial fermentations, animal cultures, or plant systems have been employed for recombinant protein production based on the type of recombinant proteins, demand, and production costs. Each of these production systems are accompanied by their advantages and disadvantages. Animal cell cultures and transgenic animals carrying harmful pathogens or prions increase the downstream processing cost for their separations. Microbial systems even though considered as best systems to obtain large quantities of proteins, they are unable to carry out post-translational modifications involving folding and glycosylation essential for eukaryotic protein activity and efficacy. Further, large scale production of heterologous proteins in microbial system is confined to inclusion bodies and extraction poses hurdles which enhances the downstream cost. Plant cells on the other hand offer advantages over mammalian and microbial systems by producing different types of eukaryotic proteins having precise folding and modification required for its activity. The dual options of using plant platform are, proteins can be produced in field grown plants or in cell cultures to achieve the required yield. Additionally, use of plants ensures enhanced production and inexpensive scale up cost, easy scaling up, high protein quantity, homogeneity, and relative safety. Albeit, there are few shortcomings in use of plants as production platforms such as slow growth cycle, variation in the yield in each cycle, and downstream processing cost. However, some of these limitations can be overcome in some exceptional cases whereby therapeutic proteins are secreted out into the liquid broth or expressed in edible tissues which can be consumed raw. These will ensure in lowering the downstream costs and decrease the yield losses.

Plants are gaining increasing importance as production platforms because of their ability to glycosylate therapeutic proteins which eventually increases the immunogenic potential and receptor binding in addition to resistance to thermal denaturation and protection from proteolytic degradation. Plants are amenable for glyco-engineering wherein efforts are directed mainly on silencing plantspecific N-glycan-processing genes, and/or the introduction of the enzymatic machinery required for synthesis, transport, and transfer of human type sugars onto the recombinant proteins [24-29]. Moreover, Cox et al. [30] demsonstarted the production of monoclonal antibody without plant specific glycosylation by knocking down the Lemna minor endogenous $\alpha-1,3$-fucosyltransferase and $\beta-1,2$-xylosyltransferase genes which resulted in the production of a single major $\mathrm{N}$-glycan species without any 
noticeable plant-specific N-glycans. Further, this monoclonal antibody had better antibody-dependent cell-mediated cytotoxicity and effector cell receptor binding activities than the ones expressed in cultured Chinese hamster ovary (CHO) cells.

\section{Various Strategies Used for High-level Expression of Heterologous Protein in Plant System}

Plants form the main source of food and medicine ever since ancient times and are generally considered to be safe for human use providing a safer alternative host system for production of desired proteins. Plants have been the major intruders on this earth suggesting the production of heterologous protein at larger quantity and at wider host range. In the most recent decade, tremendous progress has been made in heterologous protein production in plants and plant systems have become competitive alternative to the established production technologies that use bacteria, yeast, fungi, insect, and/or cultured mammalian cells. Strategies have been developed and further improved and augmented with increased knowledge and technology to use plant systems for maximum production of heterologous proteins (Fig. 1).

\subsection{Stable expression from DNA integrated into the plant genome}

Expression of heterologous protein from plant genome involves stable nuclear transformation and integration wherein whole plants can be regenerated, ultimately producing seeds or vegetative tissues which can be maintained under tissue culture conditions or in experimental farms. This involves screening of large number of transgenic lines to select a best line for protein production [31]. However, nuclear transformation ensures posttranslational modifications and subsequent storage or secretion of the proteins depending on the fused signal peptide. The accumulation of protein in cellular compartments, such as ER, chloroplast, mitochondria, and vacuole ensure appropriate folding and assembly resulting in protein stability and bioactivity. Nuclear transformation and expression of proteins have certain merits, but incurs high cost and consumes more time with generally low levels of expression of proteins [32]. The expression levels in nuclear transformation can be increased by utilizing strong promoters, enhancer elements, and augmenting other molecular strategies like codon usage or addition of strong signal sequences. But long production cycles and ability to cross with native plant species has limited its scope for commercialization.

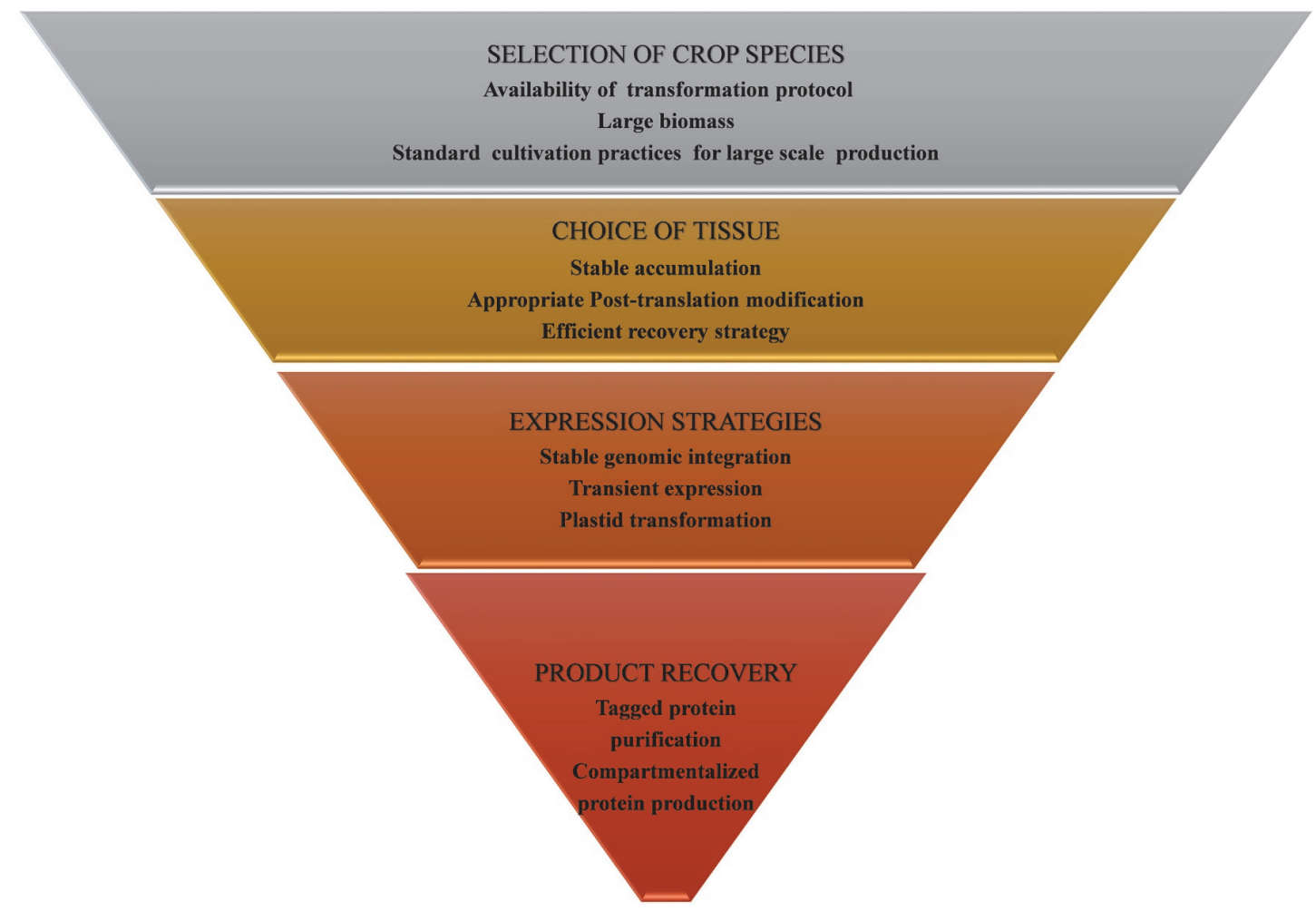

Fig. 1. Approaches for heterologous protein production in plants. 
Traditionally, interferon gamma (IFN- $\gamma$ ) which is decisive for immunity against viral, some bacterial and protozoal infections has been produced using a variety of transgenic systems including bacteria, cultured animal cells, and viruses [33-47]. Recombinant IFN- $\gamma$ expressed in plant and animal systems exhibit different glycosylation profiles, and therefore behaves differently with respect to susceptibility to proteolysis, shorter survival times in blood [48], and high production costs. Chicken interferon gamma (ChIFN$\gamma$ ) oral vaccine adjuvant was expressed in tobacco plants up to a level of 10 to $20 \mu \mathrm{g} / \mathrm{g}$ fresh leaf weight by applying codon usage and an endoplasmic reticulum retention signal [49]. The heat-labile enterotoxin B (LTB) subunit from enterotoxigenic $E$. coli and the cholera toxin B (CTB) subunit from Vibrio cholerae were produced in transgenic rice with a view to produce vaccines against these strains causing diarrhea. LTB and CTB genes were inserted between globulin promoter and potato protease inhibitor II terminator for expression in transgenic rice plants [50].

\subsection{Stable expression from the plastid genome} (chloroplast transformation / transplastomic technology) Apart from expression of recombinant protein from plant genome, plastid is also explored as a useful target for genetic manipulation and expression of heterologous proteins. The advantages of chloroplast transformation (transplastomic technology) over the nuclear transformation are: thousands of plastids present in photosynthetic cells of higher plants result in higher level expression $(46-70 \%$ of the total soluble leaf protein) of transgene with proper folding and formation of disulfide bonds [51-57]. Transgene integrated into chloroplast DNA do not appear to undergo silencing or suffer from position effects due to their site-specific transgene integration into the chloroplast genome; scope for multi-gene engineering in a single transformation event [58,59]; and chloroplast genes are inherited in a strictly maternal fashion providing a natural containment method for transgenic plants, since transgene cannot be transmitted through pollen in majority of plants $[60,61]$.

Integration of the transgene in the transcriptionally active spacer region between the $\operatorname{trn} I$ and $\operatorname{trn} A$ genes within the ribosomal operon resulted in the highest levels of transgene expression [62]. Although, chloroplast transformation has been achieved in a few important crop plants such as carrot, potato, tomato, soybean, and eggplant; expressing therapeutic proteins like subunit vaccines in the non-green edible portion is a challenging task. Edible leafy vegetables (lettuce and Brassica) could be the suitable options for chloroplast transformation and these could serve as the best source of edible vaccines [63-66].

The chief capsid protein L1 of human papillomavirus HPV-16 was expressed in tobacco chloroplast genome to a level as high as $240 \mathrm{mg}$ per mature plant. The chloroplastderived L1 protein exhibited proper conformation and assembled into virus-like particles [67]. Further, intraperitoneal injection of the leaf extract in mice showed presence of neutralizing antibodies [68]. The hepatitis $\mathrm{C}$ viral core gene and a codon-optimized gene encoding a $\mathrm{C}$-terminal truncated $16 \mathrm{kDa}$ core polypeptide were expressed in tobacco chloroplasts. Anti-core antibodies in HCV-infected human sera were detected by the $16 \mathrm{kDa}$ core polypeptide in total leaf protein [69]. Youm et al. [70] demonstrated successful production of the human b-site APP cleaving enzyme (BACE) in tobacco plants by transplastomic technology. Molecular analysis revealed the integration of tobacco aadA and BACE genes between trnI and trnA site in the plastome and transcribed as dicistron. The transgenic tobacco lines accumulated BACE protein at a level of $2 \%$ of total soluble proteins and were found to be immunogenic in mice.

\subsection{Transient expression}

The transient production system is the highest and the most convenient platform for the production of heterologous proteins in plants. The methods employed for transient expression in plants include Agrobacterium-mediated transformation or Agroinfiltration [71,72], use of virus based expression system [73,74], and Magnifection technology [75]. Magnifection technology utilizes viral vectors delivered by Agrobacterium for high level expression of several polypeptides. Myoglobin, a human heme-protein present in the muscle was successfully produced in the leaves of $N$. benthamiana by transient expression using a viral vector delivered by Agrobacterium tumefaciens. The results indicated appropriate incorporation of heme in the protein with comparable functionality as seen in the native system [76].

Among plant-based approaches, viral expression systems have shown great promise and flexibility to produce recombinant proteins on a large scale in short time [77]. Plant virus expression vectors have always been under development as one of the efficient systems for recombinant protein production in plants. Plant RNA virus (Tobacco mosaic virus, Potato virus $X$, and Cowpea mosaic virus) expression vector systems have been broadly classified as the ones which are engineered for the production of immunogenic peptides and proteins in plants (short epitopes fused to the $\mathrm{CP}$ that are displayed on the surface of assembled virus particles) and the other as polypeptide expression systems (expressing the entire recombinant protein) [78]. Viruses are the chosen system for transient expression and transformation as they can be engineered as deconstructed viruses to prevent movement from cell-tocell, be transmitted by insects to other plants or undergo unnecessary and unexpected recombination events [79]. 
Fujiki et al. [80] developed a Cucumber mosaic virus (CMV)-based expression vector for the production of heterologous proteins in plants. The CMV-based expression vector utilized truncated $3 \mathrm{a}$ protein, which expresses the target genes from the strong coat protein $(\mathrm{CP})$ sub-genomic promoter and without the need for providing $\mathrm{CP}$ in trans for cell-to-cell spread. A maximum expression level of $\sim 450 \mathrm{mg} / \mathrm{kg}$ and $\sim 170 \mathrm{mg} / \mathrm{kg}$ of leaf tissue of green fluorescent protein (GFP) and human growth hormone (hGH), respectively was obtained in $N$. benthamiana plants transformed using agroinfiltration.

Recombinant virus-like particles (VLPs) represent one of the effective vaccine strategies. A stable transgenic plant system for inexpensive production and oral delivery of VLP vaccines have been described previously. On the other hand, the relatively low-level antigen accumulation and long-time frame to produce transgenic plants are the two major obstructions in the practical development of plant-based VLP production. Geminivirus-derived DNA replicon vectors for rapid, high-yield plant-based production of VLPs has been reported by Huang et al. [81]. Codelivery of bean yellow dwarf virus (BeYDV)-derived vector and Rep/RepA-supplying vector by agroinfiltration of $N$. benthamiana leaves resulted in efficient replicon amplification and protein production up to 5 days. Coexpression of the P19 protein of tomato bush stunt virus, a gene silencing inhibitor, further enhanced VLP accumulation by stabilizing the mRNA. Concurrently, hepatitis B core antigen ( $\mathrm{HBc}$ ) and Norwalk virus capsid protein (NVCP) were produced at a concentration of 0.80 and $0.34 \mathrm{mg} / \mathrm{g}$ leaf fresh weight, respectively. This method has advantages of fast and high-level production of VLP-based vaccines using the BeYDV-derived DNA replicon system for transient expression in plants.

Chemical induction using a chemically inducible viral amplicon expression system to increase expression of a heterologous protein, $\alpha-1$-antitrypsin (AAT), in plants was optimized by Plesha et al. [82]. A cucumber mosaic virus inducible viral amplicon (CMViva) expression system was used to transiently produce a recombinant human blood protein (AAT), by co-infiltrating intact and detached $N$. benthamiana leaves with two $A$. tumefaciens strains, one containing the CMViva expression cassette carrying the AAT gene and the other containing a binary vector carrying the gene silencing suppressor p19. Application of induction solution every 2 days via topical application resulted in AAT improvement to 1.8-fold of the total soluble protein.

Recent developments in transient expression system involves the combination of plant viral sequences (based on TMV) and Agrobacterium binary plasmid (based on pBI121) termed as hybrid Launch vector (pBID4). The launch vector contains the CaMV35S promoter transcribing the viral sequences. After agroinfiltration multiple single stranded DNA copies present between the left and right borders of the T-DNA of Agrobacterium plasmid are produced in the plant cells thereby producing multiple copies of the gene of interest and high expression level. This system has been successfully demonstrated for the expression of influenza H5N1 antigens [83,84].

Magnifection is the new strategy employed at the industrial level to assure the requirements like higher-yield, rapid scale-up, and rapid production in bulk quantity. MagnICON ${ }^{\circledR}$ technology (ICON Genetics GmbH, Halle, Germany) is based on in planta assembly of functional viral vectors from two separate 5' and 3' pro-vector modules. Agrobacterium-mediated transformation helps in delivering these viral sequences into the plant cells which are then assembled in the presence of a site-specific recombinase $[75,85]$. It was proven highly effective in the production of plague antigens [86], hepatitis B virus core antigen (HBcAg) VLPs [87], Norwalk virus VLPs [88], and anti-ebola monoclonal antibodies [89].

\section{Organ Specific Expression}

Numerous approaches are employed to express proteins in different organs of plants to achieve improved yield and stability. Foreign proteins can be specifically expressed and/or enriched in leaves, fruits, roots, and seeds of plants (Fig. 2).

\subsection{Heterologous protein production in leaves}

The idea of producing heterologous protein using plant system gained importance due to its ability to produce large biomass (leaves) under natural conditions. Several tones of biomass can be collected from one to few acres of

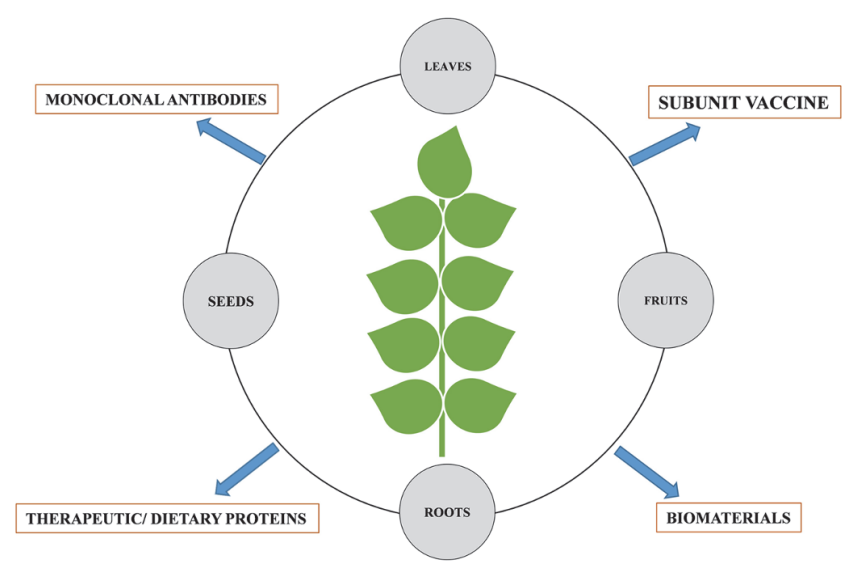

Fig. 2. Schematic representation of heterologous proteins expression in different plant parts. 
plantations. Tobacco species namely Nicotaina tabacum and Nicotiana benthamania have been the appropriate plant platforms and commonly employed to produce antibodies in leaves. The protocol for stable and transient transformation of tobacco using Agrobacterium is very well established. Nevertheless, tobacco plants produce large amount of leaf biomass in a single harvest cycle and also multiple harvest cycles can be performed per year to increase the yield per hectare. Transplastomic technology has provided maximum usage potential of plant leaves for production for therapeutic proteins and vaccines as plastids are capable of producing multimeric proteins with appropriate folds. High yield of active human growth hormone i.e., somatotropin [90] and serum albumin protein [54] have been produced in tobacco chloroplasts. A $47 \mathrm{kDa}$ tetanus toxin fragment (TetC) was successfully expressed in tobacco chloroplasts, and was capable for inducing protective levels of TetC antibodies in mice [91]. Similarly, cholera toxin B fragment fused with human proinsulin CTB-pins [92] and exendin 4 [93] were expressed in high quantities in tobacco leaves and tested for their therapeutic role in treatment of diabetes. E. coli enterotoxin B [94] and plague F1-V [95] expressed in tobacco leaves were successful in inducing an immune response and protected mice against these diseases. Nevertheless, several viral antigens were expressed in tobacco leaves with high yield and were effective in eliciting an immune response in mice. Hepatitis E virus HEV E2 [96], Swine fever virus CFSV E2 [97], and human papillomavirus L1 [68] were produced in tobacco chloroplasts. Protozoan antigens such as LecA from Entamoeba [98] and CTB-ama1 and CTB-msp1 from Plasmodium parasite [99] were produced in tobacco leaves and its potential as vaccine candidates have been evaluated. Besides tobacco, lettuce and alfalfa are the most preferred choice of plants for production of heterologous protein in leaves as they both produce large quantity of leaf biomass and lack harmful phenolic compounds like nicotine. Cholera toxin B subunit fused with the known Mycobacterial antigens; secretory antigens (ESAT6) and cell wall based lipase (LipY) expressed in lettuce chloroplasts were used for oral delivery of TB vaccine antigens [100]. Malarial vaccines namely, Pfamal and Pfmspl were produced in lettuce leaves [99] and were highly immunogenic in mice. Further, the antibodies generated in this response prevented the invasion of Plasmodium into red blood cells. A chimeric peptide (MLC) consisting of the merozoite surface protein-1 (MSP-1) and the circumsporozoite protein (CSP) separated by a poly-Gly linker motif expressed in Brassica napus was identified as a potential oral vaccine against vivax malaria [101]. Transgenic lettuce expressing the hepatitis B surface antigen $(\mathrm{HBsAg})$ was administered as oral vaccines in mice and humans. This antigen induced HBsAg antibodies in both populations to a protective level [102]. Geminiviral replicon delivery system was used for highlevel expression of virus-like particle (VLP) derived from the Norwalk virus capsid protein (NVCP) and therapeutic humanized mAbs against Ebola (EBV) (6D8) or West Nile (WNV) (hE16) viruses in lettuce [103].

Alfalfa has a strong regenerative capacity in addition to low quantities of phenolic compounds and high content of proteins which makes it suitable for expressing proteins in large quantities. The sVP6 protein of human group A rotavirus expressed in alfalfa elicited sera antibodies in mice and provided passive immunization when subjected to a challenge with simian rotavirus SA-11 [104]. The most successful achievement is the production of animal vaccines in alfalfa. Protective levels of serum antibody were generated to foot and mouth disease virus in mice after oral administration or parenteral immunization with transgenic alfalfa plants expressing the Foot and Mouth disease viral structural protein VP1 [105]. A truncated version of the structural protein E2 from Bovine Viral Diarrhea Virus (BVDV) was expressed as a fused protein in transgenic alfalfa plants [106]. Mice and bovine studies demonstrated production of $B V D V$ specific antibodies that were able to protect the animals completely from infection.

\subsection{Heterologous protein production in seeds}

Ease of collection, processing, and concentration of protein in seed tissues has made plant seeds as natural bioreactors for successful heterologous protein production. Transgenic plants are engineered to express and accumulate recombinant proteins in seeds by using seed specific regulatory sequences such as tissue-specific soybean seed storage $\beta$ conglycinin promoter [107]. Soybeans (Glycine max) are the chosen plants for seed specific expression, as these seeds are richest source of proteins and contain nearly $40 \%$ protein by dry mass [108]. Transgenic soybean seed derived vaccine was used to protect cattle from infection by enterotoxigenic E. coli (ETEC). The ETEC fimbriae subunit protein FanC antigen was overexpressed in soybean and was found to elicit immune response in mice even in the absence of cold chain transportation and storage [109]. Human proinsulin gene was expressed in transgenic soybean seeds driven by monocot tissue-specific promoter from sorghum $\gamma$-kafirin seed storage protein gene and the $\alpha$-coixin cotyledonary vacuolar signal peptide from Coix lacryma-jobi. Proinsulin accumulated in soybean seeds and was found to be stable even after 7 years under room temperature conditions [110]. Heat-labile enterotoxin B (LTB) subunit from enterotoxigenic $E$. coli was expressed in soybean seeds [111] and rice seeds [50] and used as oral vaccines to immunize mice against ETEC. The toxinneutralizing activity of LTB in serum of orally immunized 
mice was due to the action of both IgG and IgA responses.

Murine single-chain variable fragment $(\mathrm{scFv})$ was accumulated in transgenic Arabidopsis seeds, as high as $12.5 \%$ and $36.5 \%$ of total soluble proteins using the $5^{\prime}$ and $3^{\prime}$ regulatory sequences of the seed storage protein gene arcelin 5-I and beta-phaseolin seed storage protein promoter from Phaseolus vulgaris, respectively [112,113]. Additionally, single-chain variable fragment-Fc antibodies neutralizing hepatitis A virus [114], porcine reproductive and respiratory syndrome virus glycoproteins [115] and human lysosomal acid $\beta$-glucosidase protein [116] was expressed in transgenic Arabidopsis seeds and assessed for their immunogenicity. Numerous antigens have been expressed in corn seeds owing to high biomass yield, bigger endosperm, absence of active proteases in dry seeds and presence of a rich mix of molecular chaperones and disulfide isomerases for proper folding of proteins and the very well-established processing technology $[117,118]$. Heat labile B subunit from enterotoxigenic E. coli, cholera toxin B subunit from $V$. cholerae, spike protein of swine transmissible gastroenteritis, hepatitis $\mathrm{B}$ oral vaccine and human recombinant proinsulin was efficiently expressed in corn plants [119-124].

Rice is another apt candidate next to corn to express heterologous proteins with the additional advantage of selfpollination and cultivated in most parts of the world. Rice seeds were engineered to produce therapeutic proteins like human serum albumin [125], single chain variable fragment against a tumor-associated marker antigen-carcinoembryonic antigen [126], and interleukin 10 [127]. The major T-cell epitopes from Japanese cedar pollen allergens Cryj1 and Cryj2 were expressed in the endosperm of rice seeds $[128,129]$. Mice fed with these transgenic rice seeds daily for three weeks and then challenged with cedar pollen allergen showed significant suppression of allergen-specific $\mathrm{CD}^{+}{ }^{+} \mathrm{T}$-cell proliferation, IgE and IgG levels. Such studies can be further used for developing potential human vaccines for oral administration as tolerogen formulations [130]. Few reports in recent past also demonstrated production of therapeutic proteins in seed tissues such as hepatitis B surface antigen in tobacco seeds [131], hepatitis C core antigen in B. napus seeds [132], and antihypertensive peptide in rice seeds [133]. Other plants have also been investigated for production of recombinant proteins in seeds but cereals and legumes have been the favored choice. However, there is a strong opposition for producing therapeutic proteins in such food crops because of the contamination issues with non-transgenic plants under non-stringent conditions.

\subsection{Heterologous protein production in fruits and vegetables}

Fruit can serve as one of the best plant organs for production of therapeutic proteins and oral delivery of vaccines because they are consumed raw and hence the expressed proteins will retain their natural conformation imparting more immunogenicity. Tomatoes have been used for expression of heterologous proteins owing to the easy availability of transformation protocol, capability to increase biomass with low cost under greenhouse conditions and the short life cycle. Additionally, the amount of protein content in raw tomatoes is more as compared to the ripened tomatoes. Yersinia pestis F1-V antigen fusion protein expressed in tomato fruits and administered orally in mice developed immunogenicity when challenged subcutaneously with bacterially produced F1-V [134]. An edible diphtheriapertussis-tetanus (DPT) multicomponent vaccine was expressed satisfactorily in transgenic tomato plants by combining the exotoxin epitopes from Corynebacterium diphteriae, Bordetella pertussis, and Clostridium tetani [135].

Proteins expressed in fruit tissue undergo post-translation modification and form biological active oligomers. E. coli heat-labile enterotoxin B subunit when expressed in plant was able to form active pentamers and specifically bind to GM1 ganglioside [136]. A range of viral antigenic proteins, such as rabies virus glycoprotein G [137], respiratory syncytial virus F glycoprotein [138], a hepatitis E virus surface protein [139], rotavirus capsid protein VP2 and VP6 [140], a synthetic HBV/HIV antigen [141], Norwalk virus capsid antigen [142], hepatitis B virus surface antigen (HBsAg) [143] chimeric human papilloma virus HPV-16 L1 proteins were expressed in tomatoes [144]. Other industrially important product engineered in tomato fruits includes a taste-modifying protein, miraculin which functions to change the perception of a sour taste to a sweet one [145].

Transgenic banana plants have been used to produce HBsAg in fruits with a view to use it for vaccination through banana fruits [146]. But the lower yield of this antigenic protein in banana fruits raised a problematic technical issue for its use as a vaccine. The difficulty of accumulating heterologous proteins in ripened fruits such as banana has always hindered the system to be used for vaccine delivery. Another study claimed production of cholera toxin B subunit in transgenic banana callus [147].

Strawberries have been used as candidate for production of recombinant proteins as fruits are eaten raw, store good amount of protein and strawberry plants are propagated vegetatively thus lessening the risk of gene contamination. A Japanese firm had setup a plant under the METI project for production of canine interferon (IFN $\alpha$ ) from transgenic strawberries [148]. Later these transgenic strawberries expressing dog interferon- $\alpha$ were powdered and sold as an oral drug from 2014 and was found to be effective in the treatment of periodontal disease $[149,150]$. 


\subsection{Heterologous protein production in roots/tubers}

Transgenic potato tubers are used for the last few years as a source for heterologous proteins due to key properties such as long-term storage of accumulated protein in stable form, plentiful of biomass, short growth cycle and certainly the ability to induce mucosal immunity on oral administration $[151,152]$. Transgenic potato plants constitutively expressing the synthetic $E$. coli heat-labile enterotoxin subunit B (LTB) gene which has increased accumulation and pentamers assemblage of LT-B in leaves and tubers. Raw tubers fed to mice in three doses were able to generate higher levels of serum and mucosal anti-LT-B antibodies [153]. Cholera toxin B subunit protein was expressed in potato tubers and was able to induce serum and intestinal anti-CTB antibodies $[154,155]$. Transgenic potato tubers have also been used to produce viral antigens such as hepatitis B surface antigen [156,157], Norwalk virus coat protein [158,159], epitope of porcine epidemic diarrhea virus [160], GP5 protein of Porcine reproductive and respiratory syndrome virus [161], Rotavirus VP7 [162], infectious bronchitis virus (IBV) S1 glycoprotein [163], and human papilloma virus major capsid protein L1 [164,165] or oncogene E7 [166] as oral vaccine candidates. Yu and Langridge [167], constructed a combination of Cholera toxin B and A2 subunit, rotavirus enterotoxin and enterotoxigenic E. coli fimbrial antigen genes and were expressed in transgenic potatoes. This fusion protein was assembled into cholera holotoxin-like structures having enterocyte-binding affinity and elicited immune response against diarrheal symptoms.

Transgenic potato tubers have also been used to produce other therapeutic proteins and nutraceuticals. Soybean agglutinin (SBA), an N-acetylgalactosamine-binding plant lectin finds application in screening and treatment of breast cancer, fetal cell screening, purification of tagged proteins and carrier for drug delivery. The SBA produced in transgenic potato tubers was highly resistant to degradation by gastric secretions and also retained its specific binding activity [168]. Human beta-casein protein was expressed in potato plants with a view to replace bovine milk in baby foods which is responsible for gastric and intestinal diseases in children [169]. Further, Chong and Langridge [170] also expressed human lactoferrin gene in potato tubers to a level approximately $0.1 \%$ of total soluble proteins. A cholera toxin B subunit-Insulin fusion protein was produced in transgenic potato tubers at a concentration of $0.1 \%$ of the total soluble proteins. Non-obese diabetic mice fed with these potato tuber tissues showed reduction of inflammation of pancreatic cells and delay in diabetes disease progression [155]. In another study, ricin subunit B from castor bean was used as an immunomodulatory molecule capable of enhancing immunosuppression associated with Type I diabetes [171]. Subtypes of human and salmon interferon alpha was produced in transgenic potatoes and effectively tested for their bioactivity against viral strains [156-158]. To increase the nutritional quality of potato tubers, AmA1 gene from Amaranthus hypochondriacus was transformed into potato plants in a tuber specific manner. This protein is rich in all essential amino acids for optimal human nutrition [172].

Other plant tubers used for heterologous protein expression includes carrot, sweet potatoes, and turnips. The fusion protein CFP10-ESAT6-dIFN derived from Mycobacterium tuberculosis genes was synthesized and used to transform carrot tissue. The protein was produced in transgenic carrot root tissues and was able to induce both humoral and cellmediated immune responses in mice [173]. Y. pestis F1 and $\mathrm{V}$ antigens were produced in transgenic carrot roots and were able to elicit protective levels of antibodies [174].

Hairy root cultures have been standardized for the commercial-scale production of secondary metabolites. These root cultures have also been exploited to produce heterologous proteins in larger amounts in continuous bioreactor cultures. Hairy roots offer unique advantages because of their genetic and biosynthetic stability, fast doubling time, require simple hormone free medium and easy scalable protein production. Transgenic tobacco hairy root cultures were engineered to produce human acetylcholinestarase [175], active antimicrobial peptide ranalexin [176], CD20-specific 2B8-Fc $\Delta \mathrm{XF}$ recombinant antibody [177], and recombinant human erythropoietin [178]. Tobacco hairy root cultures were also used for the production of murine interlukin 12 [179]. A study demonstrated use of Brassica rapa (turnip) hairy root cultures over tobacco cultures for better production capability and stability of heterologous proteins. An isoform of human growth hormone was produced in Brassica oleracea hairy root cultures. The $B$. rapa hairy root cultures showed that the recombinant protein is characterized by highly homogeneous post translational profiles enabling a strong batch to batch reproducibility and highlighting the high homogeneity of the production system [180,181]. Although the recombinant proteins are accumulated or secreted by hairy root cultures in large quantities, proteins are degraded by the proteolytic activity of peptidases. Nevertheless, studies are underway to inactivate these peptidases genetically or biochemically.

\section{Boosting Plants as Heterologous Protein Production Systems}

Research in heterologous protein production in plant is now oriented for increasing the recombinant protein production to cut down overall production and downstream 


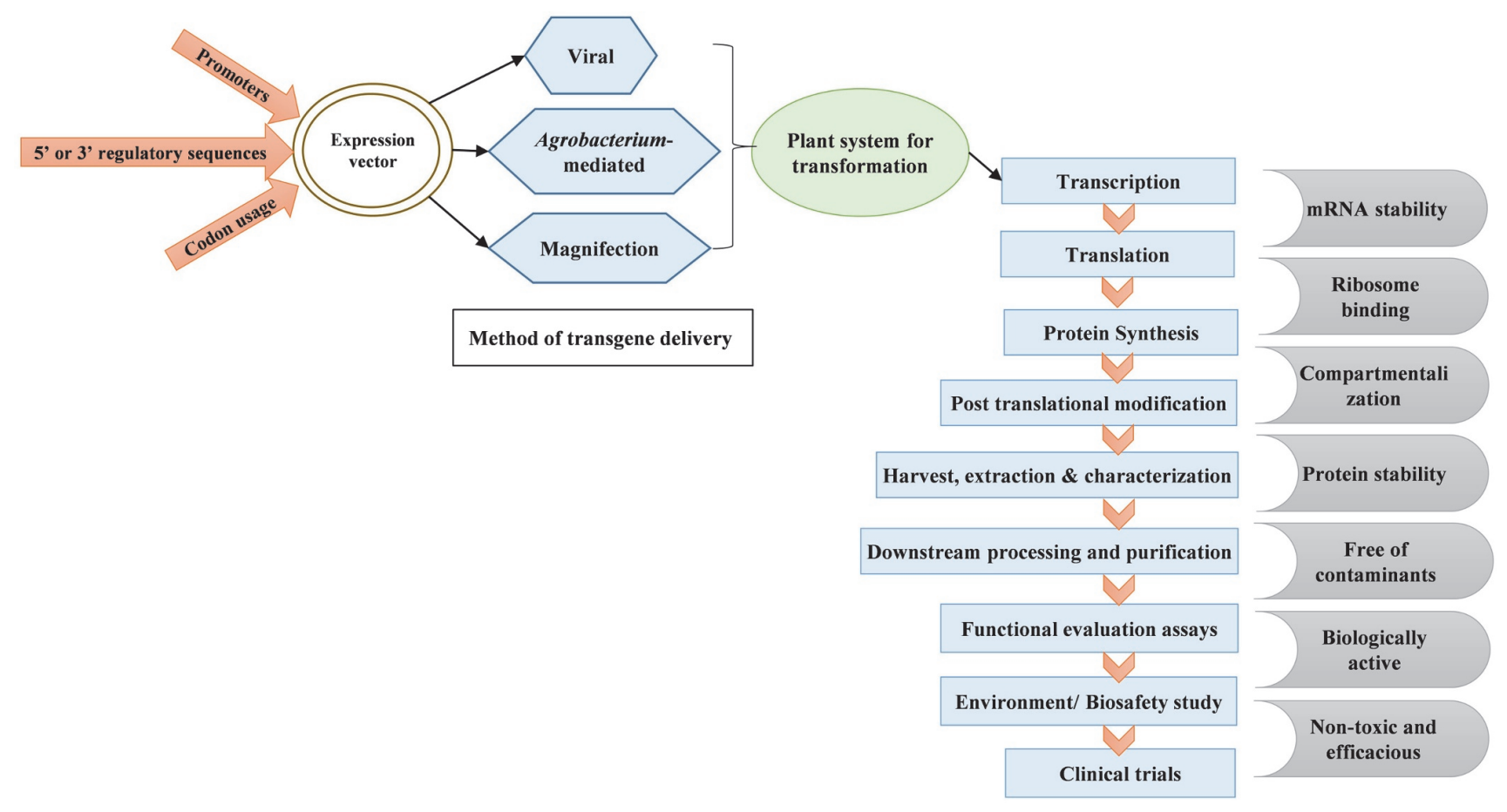

Fig. 3. Schematic representation of stages involved in heterologous protein production in plants along with factors affecting final product output.

cost. Several strategies have been implemented to enhance protein production in plants by modulating regulatory sequences like promoters, 3' UTRs, increasing transcription rate and transcript stability, efficient translation and compartmentalization for higher accumulation (Fig. 3). A number of constitutive and tissue specific promoters have been used for high level protein production. The most widely used constitutive promoter is the Cauliflower mosaic virus $35 \mathrm{~S}$ promoter (CaMV35S) which has shown to drive strong expression of the downstream gene of interest in most of the plant species. Alternatively, other constitutive promoters used for plant transformation include ubiquitin, actin, histone, tobacco cryptic promoter, and nopaline synthase promoter to list a few [182-185]. Chimeric promoters or combination of viral promoters have been created to enhance the expression level. Elements from the Commelina Yellow Mosaic Virus (CoYMV), the Cassava Vein Mosaic Virus (CsVMV) and activating sequences from the CaMV35S promoter were combined together to drive strong expression of the downstream reporter gene $[185,186]$. Selected tissue specific promoters have also been utilized to accumulate and compartmentalize recombinant proteins which affect protein stability and downstream processing. Several root, fruit, tuber, and seed specific promoters have been isolated. Furthermore, to achieve high level of expression of the heterologous protein multiple enhancer elements from strong promoters can be stacked upstream of gene of interest which will increase the transcription rate. Another way to increase the transcriptional activity is to insert scaffold or matrix attachment regions next to the promoter sequence which helps in the recruitment of transcription factors and polymerases. Duan et al. [187] heterologously transformed Arabidopsis chimeric myosin XI-2 gene in Camelina and the transgenic plants exhibited not only enhancement of leaf development, total seed yield and main stem elongation but also early flowering and seed setting, indicating that the high-speed chimeric myosin XI-2 can improve plant growth in Camelina.

Inducible promoter systems offer the opportunity to regulate gene expression levels at particular stages of plant growth and development and in particular tissues of interest. Thus, the overexpression of heterologous protein will not hinder normal growth and development and can be accumulated with higher yields at the right stage for easy downstream processing. The expression can be triggered by external elicitors like ethanol, tetracycline, dexamethasone, copper, salicyclic acid, salts, and sugars and by environmental factors like temperature and oxidative stress or by pathogens [188]. Dugdale and his team [189] developed a technology termed as INPACT (프 Planta Activation) used for inducible high level expression of protein in tobacco plants. The INPACT cassette is assembled in such a way that on infection by tobacco yellow dwarf virus, the recombinant 
gene is split and expressed from the extra chromosomal, replicating episomes which are set free from the host chromosome in the presence of the virus-encoded replication associated proteins, Rep/RepA transcriptionally controlled by the AlcA:AlcR switch responding to ethanol application. Using INPACT technology bovine trypsinogen and human vitronectin was expressed in tobacco leaves to a level of up to $196 \mathrm{mg} / \mathrm{kg}$ (dry weight) and $\sim 100 \mathrm{mg} / \mathrm{kg}$ (fresh weight), respectively.

Transcription levels mostly cannot be correlated to the amount of protein accumulated as it depends on several factors such as efficient 5'capping, mRNA splicing, polyadenylation, nuclear export, and mRNA stability in the cytosol. However, all these factors can be manipulated to enhance protein production in plant systems. Insertion of a strong 3' UTR downstream to the gene of interest in the expression vector takes care of the polyadenylation and mRNA stability. Commonly used terminators are nopaline synthase, cauliflower mosaic virus 35S, heat shock protein and potato proteinase inhibitor II 3'UTRs [190-192]. Position and the sequence of an intron have significant effects on expression levels of the proteins in plant cells. Thus, intron sequences are modulated in the synthetic gene constructs to achieve maximum expression levels [189, 193,194].

Translational efficiency of the protein sequences can be increased by inserting a leader sequence or manipulating native 5'UTR sequence with the objective to increase ribosome binding and thereby translation. In addition to augment protein production, codon optimization can be carried out during designing the gene of interest. During this procedure some rarely utilized codons can be removed and replaced by the codons commonly recognized from the available pool of t-RNAs in plants. Precise engineering is warranted depending upon the type of transformation as codon usage for nuclear and plastid genes are varied. To obtain proteins in their biological active form, they undergo post translational modifications such as glycosylation, phosphorylation, methylation, and ribosylation. Post translational degradation of proteins can be effectively reduced by subcellular compartmentalization. Proteins can be sequestered to organelles like endoplasmic reticulum, vacuoles, mitochondria, and plastids. Addition of ER retention signal (KDEL/ HDEL) or mitochondrial/plastid signal sequences can direct the transport of nascent peptide to the respective organelle. ER targeting helps in safeguarding the proteins and ensures proper folding and assembly because of the resident chaperone machinery $[195,196]$. C-terminal fusion of the KDEL peptide, an ER retention signal to single-chain antibody variable-region fragments has been found to increase antibody levels by a factor of up to 10-100 as compared to either extracellular secretion to apoplast or expression in the cytosol [197]. Proteins which can accumulate and are stable under acidic conditions can be sequestered to the vacuoles. Few Nterminal and C-terminal propeptide sequences have been identified that routes the protein to vacuoles. Plastids in plants are the next important organelles to accumulate proteins up to $70 \%$ of the total soluble proteins. Proteins can be diverted to plastids by adding unique signal sequences or can be inherently produced in plastids by transplastomic technology described before. Most proteins produced and channelized through endomembrane system find their way to the apoplast. The proteins secreted into the apoplastic region avert intracellular and vacuolar proteinases. If these proteins are large enough, they accumulate between the cell membrane and cell wall and if small then are secreted into the medium. Secretion of proteins into the medium reduces the downstream cost and helps in easy recovery of the proteins. However, these secreted proteins are constantly exposed to harsh conditions or some extracellular proteinases which degrade the proteins and reduce the production yield. Co-expression of proteinase inhibitors or protease-resistant fusion constructs have increased the production of recombinant proteins in plant systems [198-202].

\section{Bioreactors for Recombinant Protein Production in Plant Cells}

Plant cell suspension cultures offer best platform for stable accumulation and secretion of recombinant protein in large quantities. Generally, plant nutrient media are relatively simple salt solutions with no added proteins and if a heterologous protein is produced in tissue culture and secreted into the medium, product recovery and purification could be easily and efficiently worked out due to absence of large intracellular contaminating proteins. Several studies have demonstrated secretion of proteins into medium which are less than $30 \mathrm{KDa}$ whereas higher molecular weight ones are retained inside the cell due to plant cell wall. This problem is overcomed by incorporating a signal sequence before the gene of interest so as to secrete the protein into the culture medium. Use of bioreactors have facilitated up scaling and increase the production of recombinant proteins to a level equivalent to bacterial or mammalian system $[203,204]$. Although, the technology of producing recombinant proteins in cell suspension cultures was proven more than 25 years before, the cost and potential to scale up to industrial level was not a very successful venture [16]. During this time, different bioreactors were designed to overcome this hurdle that included the stirred tank and wave bioreactor. Both stirred tank and 
airlift bioreactor were used for the production of murine granulocyte macrophage-colony stimulating factor (mGMCSF) in transgenic $N$. tabacum cells [205]. A new type of bioreactor designed by Protalix Biotherapeutics consisted of large polyethylene bags serially arranged and filled with medium and supplied with sterile air to produce recombinant human $\beta$-glucocerebrosidase [206].

Carrot cells and tobacco BY-2 cells are commonly used cell cultures for production of therapeutic, pharmaceutical, and vaccine proteins [206,207]. A number of therapeutic proteins have also been expressed in rice cell cultures. Following are a few proof of principle studies demonstrating the production of foreign protein in rice cell suspension cultures. Human cytotoxic T-lymphocyte antigen 4immunoglobulin (hCTLA4I g) driven by rice alpha-amylase 3D (RAmy3D) promoter was expressed in transgenic rice cell suspension culture. Purified hCTLA4IgP was found to be biologically active and suppressed T-cell proliferation [208]. mGM-CSF fused with the $\alpha$ Amy 3 signal peptide was produced in rice cell suspension cultures scaled up in a 2-L bioreactor and yielded highest concentration of $24.6 \mathrm{mg} / \mathrm{L}$ protein in the culture filtrate [209]. A Der p2FIF-Fve fusion protein was expressed in rice cells under the control of sucrose starvation induced $\alpha$-amylase gene ( $\alpha$ Amy 8$)$ the fusion protein elicited IgE immunogenicity and histamine release [210]. Similarly, recombinant alpha1-antitrypsin [211], human growth hormone [212], and Interferon-gamma (IFN- $\gamma$ ) [44] was also expressed in rice cells.

Currently mosses such as Physcomitrella patens, have been employed as platforms for production of therapeutic proteins in bioreactors [213,214]. Owing to their photosynthetic property and glycosylation capability, $P$. patens has become a best alternative to produce high value humanized proteins with reduced production costs. Simple designed bioreactors are employed to grow this moss for production of therapeutic proteins such as vascular endothelial growth factor [215], erythropoietin [216], the complement-regulatory protein factor H [217], HIV epitopes from gp120 and gp41 [218], glyco-optimized antibody IgG1 IGN314 [219], and enzymes such as human alpha-galactosidase and glucocerebrosidase [220]. With increasing knowledge and technical know-how plant cell cultures can be efficiently utilized to produce large quantities of therapeutic proteins at par with bacterial and mammalian platforms with reduced cost.

\section{Plant Derived Protein in Clinical Trials}

\subsection{Antibodies}

To date, several antibodies have been synthesized in a variety of plants having applications in medical, industrial, and research fields. Production of antibodies in plants has gained importance owing to its reduced cost. Effective protection against some serious diseases like AIDS requires continuous application of HIV neutralizing antibodies $[221,222]$ which will dramatically increase the cost per application. In such cases, scaling up production becomes more important than speeding the reaction; and therefore transgenic plant production platform become more pertinent because of their rapid scaling up capacity. In one prominent study antibody cocktails (ZMapp) produced in tobacco plants ( $N$. benthamiana) using MagnICON technology was used for treating Ebola infection in non-human primates [89]. Off lately, a high level production of monoclonal antibodies using an optimized plant expression system has been reported [223].

A few number of antibodies expressed in plants reached the clinical trials and soon to be launched in the market. A chimeric secretory antibody CaroRx (IgG-IgA) that binds to the bacteria Streptococcus mutans, a causative agent of tooth decay, was expressed in tobacco plants. This antibody is effective as it protects against dental caries and prevents the recolonization of the bacteria up to 2 years after 3 weeks of application [224]. An anti-CD20 optimized antibody BLX-301 was produced in aquatic plant $L$. minor (duckweed) by Biolex Inc. which entered the phase I trials for the treatment of non-Hodgkin's B cell lymphoma and rheumatoid arthritis [30]. MAPP66 is an antibody cocktail produced in $N$. benthamiana by Icon Genetics (Bayer's) MagnIcon technology and used as a HSV/ HIV microbiocide which entered first phase clinical trial (Mapp Biopharmaceutical, Inc.). Four anti-HIV neutralizing monoclonal antibodies namely b12, 2G12, 2F5, 4E10 were found to be effective in controlling the transmission of virus [225]. Out of these four antibodies, 2G12 antibody produced in transgenic tobacco by Pharma-Planta has been approved for the first-in human phase I clinical trial in UK [226]. The success of these trials will mark a significant achievement in the field of plant derived pharmaceuticals and will further boost in the transfer of proof of principle studies to commercialization.

Few plant derived antibodies have also been used in manufacturing other biopharmaceuticals. CIGB, a Cuban company, has developed and produced $\mathrm{ScFv}$ monoclonal antibody (CB-Hep1) in transgenic tobacco which has been used for several years for the purification of recombinant Hepatitis B subunit vaccine [227].

\subsection{Antigen/subunit vaccines}

Plant based recombinant vaccines can be categorized as one used for veterinary and other as human vaccines. Plant-based human vaccines are not yet commercialized, 
although, proof-of-principle studies of viral and bacterial subunit vaccines have been successfully demonstrated in transgenic plants such as tomato, potato, banana, maize, alfalfa, and soybean. Developing countries are most of the time inflicted with diseases that results in mortality. Plants serve as the best alternative for production of vaccine candidates with reduced cost and thereby decrease the overall cost burden involved in conventional methods for procuring recombinant vaccines. The first plant derived vaccines approved for clinical trial was for the veterinary use which protect against Newcastle disease [228]. Dow AgroSciences (USA) produced USDA approved hemagglutinin and neuraminidase of Newcastle disease virus in tobacco cells for subcutaneous application, but is yet to be marketed [78]. Only few of the plant derived human vaccine subunits reached the clinical trials. Heat-labile enterotoxin B subunit (LTB) of enterotoxigenic E. coli (ETEC) produced either in potato or maize was the first to enter clinical trial to protect against diarrhea. Raw mashed transgenic potato or corn meal suspended in water and administered orally to healthy volunteers was observed for its safety and immunogenic potential. The study showed that volunteers fed with transgenic tissues had increased levels of LTB-specific serum IgG and IgA as compared to the placebo controls who were fed with non-transgenic potato/corn [229,230]. In another study, a major capsid protein of Norwalk virus was expressed in transgenic potato and used to feed 24 healthy volunteers [159]. Each volunteer was administered 2-3 doses as raw diced potatoes containing $215-751 \mathrm{mg}$ of NVCP. Ninety-five percent of the volunteers showed significant levels of serum IgG and stool IgA. This vaccine is currently being optimized for commercialization under the trade name NoroVAXX [231].

Hepatitis B virus disease persists even after vaccines were developed more than three decades ago. Despite of several attempts to develop oral vaccines for Hepatitis B viral disease in plants like potato and banana, no plant derived vaccine could be commercialized so far but expected to yield promising results in the near future. However, purified antigens derived from plants were immunogenic, but the inherent levels of these antigens in the tissues were found to be considerably low for using it as an edible vaccine. Nevertheless, HBsAg expressed in transgenic potato and lettuce plant was used as oral vaccines for phase I trials. More than $50 \%$ of the volunteers fed with transgenic potato showed increased levels of anti-HBsAg antibodies in the serum and developed systemic resistance response to Hepatitis B infection [151,156]. Likewise, HBsAg expressed in transgenic lettuce leaves (0.1-0.5 $\mu \mathrm{g}$ of HBsAg per $100 \mathrm{~g}$ of fresh tissue) were given to adult volunteers with reducing doses in two consecutive months [102]. Two of three vaccinated volunteers showed presence of HBsAg-specific IgG, 2 weeks after the second vaccination. Further, no IgA specific antibodies for HBsAg were detected and there were no noticeable side effects observed after ingestion of transgenic lettuce.

Endemic rabies is the common cause of mortality in some parts of the world. Therefore, there is a need for constant supply of rabies vaccines in these regions. Two rabies virus epitopes, glycoprotein (GP) and nucleoprotein (NP) were fused together and expressed in transgenic spinach under the driving control of recombinant Alfalafa mosaic virus machinery [232-234]. Raw spinach leaves were fed to two groups of volunteers, one group who were previously vaccinated for rabies virus and the other nonvaccinated group. In all more than $50 \%$ of the volunteers from both the groups displayed elevated levels of sera $\operatorname{IgG}$ able to neutralize rabies virus particles.

Influenza virus is a frequently mutating strain that results in the antigenic shift which quite often obliterates crossprotective immunity of the host. In such a scenario, strain specific vaccines produced on a large scale in short period of time are the prime requirement to prevent disease pandemics. D'Aoust and team [235] expressed haemagglutinin (HA) from strains A/Indonesia/5/05 (H5N1) and A/New Caledonia/20/99 (H1N1) by agroinfiltration in $N$. benthamiana plants. The virus-like particles assembled and accumulated in the apoplastic region of tobacco cells and was able to elicit immune response in mice. Phase I / II clinical trial of the VLP composed of HA protein of H5N1 influenza virus (A/Indonesia/5/05) (H5-VLP) has been completed. Both H1 and H5 VLP vaccines elicited significantly greater $\mathrm{CD} 4^{+} \mathrm{T}$ cell responses than placebo and persisted even after 6 months of vaccination [236,237]. Additionally, some volunteers developed antibody response to plant glycans which subsided within 6 months in most volunteers [238]. Medicago Inc. have taken up this project and completed phase I trial with the H1N1 epitope and further the test for trivalent synthetic vaccine for other strains of influenza is underway.

Few years back the rapid spread of H1N1 strain in the developing countries urged the need to produce cheap vaccines in a large quantity. Plant based VLPs were produced to develop subunit vaccines which are immunogenic. Recombinant hemagglutinin proteins from A/California/ 04/09 (H1N1) and A/Indonesia/05/05 (H5N1) strains of influenza virus were produced in $N$. benthamiana plant on a large scale. The production of serum hemagglutination inhibition and virus neutralizing antibodies was studied in laboratory animals [239]. To further enhance the overall potency of these antigens as vaccine candidates, Shoji et al. [240] constructed H1 HA VLPs (HAC-VLPs) using ectodomain of HA from A/California/04/09 strain. The recombinant hemagglutinin protein (HAI-05) from the A/ 
Indonesia/05/2005 (H5N1) strain of influenza virus was produced transiently in $N$. benthamiana using 'launch vector'. In the phase I clinical trial, the immune response elicited in volunteers by the HAI- 05 vaccine was variable with respect to both hemagglutination-inhibition and virus neutralization antibody response [241]. Correspondingly, a first-in-human, Phase I dose dependent study was conducted to investigate safety, reactogenicity, and immunogenicity of an HAC1 formulation at three dosages with and without Alhydrogel (®), in healthy adults 18-50 years of age [242]. In both the phase I trials, the vaccine was generally safe and was well tolerated, with no reported serious adverse events.

Fraunhofer Center for Molecular Biotechnology, Plymouth, MI, USA completed phase I trials for recombinant protective antigen (rPA) against anthrax disease in the year 2014. Plasmodium falciparum surface protein Pfs 25 expressed in $N$. benthamiana plants by tobacco mosaic virus-based launch vector was able to induce serum antibodies with complete transmission blocking activity [243]. The Pfs25VLP is in phase I trial and currently undergoing optimization (Fraunhofer Center for Molecular Biotechnology, USA). All these studies demonstrate the safety and immunogenicity of a plant-produced subunit vaccine in healthy adults and propose testing of novel candidate vaccines in human volunteers and further commercialization of these plant derived vaccines to combat severe diseases.

Presently with novel coronavirus responsible for an ongoing human pandemic (COVID-19), researchers have offered plants as platform for rapid supply of SARS-CoV2 antigens and antibodies for diagnostic, vaccines, and treatment therapies. In a proof-of-concept study the receptor binding domain (RBD) of SARS-CoV-2 was transiently expressed in $N$. benthamiana to a level of $8 \mu \mathrm{g} / \mathrm{g}$ leaf fresh weight at 3 days post-infiltration [244]. Biopharmaceutical companies such as ZYUS Life Sciences Inc. and iBio, Inc. are using plant-based expression system for producing SARS-CoV-2 antigens.

\subsection{Therapeutic proteins/nutraceuticals}

Several recent studies have validated the potential of nutraceuticals to improve health and prevent chronic illnesses like cardiovascular, cancer, diabetes, obesity, and multiple immune dysfunctions. Because of its nutritional benefits, safety, and therapeutic role, the market for nutraceuticals is expanding every year. Plant derived products such as flavonoids, sterols, tannins, and glucosinolates are the important source of such nutraceuticals and increasing the amount of these metabolites is the primary goal for commercialization. Recombinant glucocerebrosidase called as Elelyso (taliglucerase alfa) was produced in carrot cells for the treatment of Gaucher disease [245]. Gaucher's disease is a lysosomal storage disorder caused by mutations in the gene encoding glucocerebrosidase (GCD) resulting in the deposition of lipids in spleen, liver, and other organs. Taliglucerase alfa produced by Protalix Biotherapeutics (Israel) and licensed by Pfizer (USA) was administered orally into human patients. Phase I clinical trials displayed presence of the enzyme in the blood stream of the patients with no side effects. Phase $2 a, 2 b$, and 3 trials are under way along with other pharmacokinetics studies.

SemBioSys Genetics Inc., a Canadian biotechnology company produced an insulin molecule in safflower (Carthamus tinctorius) at commercially viable levels [246]. The Phase I/II clinical trial conducted in Europe has demonstrated clinically significant results and safety profile comparable to pharmaceutical grade human insulin. The Company submitted the Investigational New Drug application to the US Food and Drug Administration and prepared for first clinical trial in 2008 and planned phase 3 trials in 2009-10.

Recombinant gastric lipase for the treatment of pancreatic and cystic fibrosis was produced in maize seeds and entered phase II clinical trials in Europe in the year 2004 and currently marketed under the brand name Meripase (http://www.meristem-therapeutics.com). Maize modified with human lactoferrin (LacrominTM) was field tested by Biochem SA Company and by Meristem Therapeutics Company in France for the treatment of gastrointestinal infections [247]. Ventria Biosciences obtained approvals to carry out field trials (later disapproved by US Food and Drug Administration) of transgenic rice expressing lactoferrin and lysozyme intended for production of iron supplements and antimicrobial activity [248-250]. Recombinant Human Intrinsic Factor useful for vitamin B12 absorption was engineered in Arabidopsis seeds and is marketed by Cobento Biotech AS [251].

Field trials of low-nicotine tobacco varieties expressing human interleukin-10 (HIL-10) was carried out in Canada (Southern Crop Protection and Food Research Centre, Canada). HIL-10 which is used for the treatment of inflammatory bowel syndrome and Crohn's disease was produced in tobacco. Oral administrations of transgenic tobacco expressing HIL-10 reduce the severity of colitis by down-regulating TNF-alpha expression in IBD-susceptible IL-10(-/-) mice [252]. Biolex (USA) used duckweed plants to produce fibrinolytic drug for blood clots and lactoferrin for Hepatitis B \& C virus disease which are under phase I and phase II trials respectively (Biolex Therapeutics Inc.). Planet Biotechnology's (http://www.planetbiotechnology.com) $\alpha$-galactosidase (for Fabry disease) produced in tobacco and SemBioSys's (http://www.sembiosys.com) Apolipoprotein (for cardiovascular problems) produced in safflower were also approved for phase I trials and expected to reach 
market soon. Few of the therapeutic proteins such as virtonectin (Farmacule Bioindustries Pty Ltd) and thyroid stimulating hormone receptor (NEXGEN Biotechnologies, Inc.) are used mostly for research purposes and available from the company. Epidermal growth factor produced in tobacco plants are supplied by Plantderma (http:// plantaderma.es/es/), used in cosmetology for improving skin properties.

\section{Concluding Remarks}

Production of antibodies, vaccines, and other therapeutic proteins in plants shows great promise as recombinant proteins can be rapidly produced on large scale with low cost compared to other production systems. Most of the plant derived pharmaceuticals are in clinical trials and many are under investigation. Governing bodies in developed countries are involved in addressing and conceptualizing the manufacturing and application guidelines to ensure safety, efficacy, and consistency of these plant derived pharmaceuticals. Over the last few decades biofarming in plants has made significant progress to retort several shortcomings in the production system and regulatory issues (biosafety and risk assessment) and reached a stage where it can challenge the established production technologies that use bacteria, yeast, and mammalian cells. With the successful application of plant derived ebola vaccine ZMapp by Mapp Biopharmaceutical Inc., to combat the 2014 Ebola virus outbreak in Africa has once again evoked the interest of plant derived pharmaceuticals. The plant biotechnology community is extremely energetic in providing plant-based therapeutics to tackle the current COVID-19 pandemic. This will create a prototype for producing low cost, rapid, and effective therapeutics in plants for future pandemics. Current scenarios have changed the mindset from using plants as edible vaccines to utilizing them as production platforms. Additionally, proteins produced in plants are properly folded and posttranslationally modified which can further be formulated as vaccines and therapeutics. Bioreactor is the most promising approach to effectively use plant cells to produce heterologous proteins which involves low capital investment with enhanced product yield. Multinational companies like Protalix, Bayer, Icon Genetics, Meristem therapeutics are testimony to this. The studies carried out at several institutes and industries all over the world with a view to commercialize these products explain the tremendous potential of protein production in plants. Although the scientific community is aware of this fact, still an extensive work is warranted to establish plant production platform as unanimously accepted approach for vaccine and therapeutic protein production. Remarkable progress in molecular biology currently underway across the globe will definitely open new feasible options for the production of several bio pharmaceuticals. Additionally, synthetic biology is an enabling machinery that aims to increase extrapolative capacity and reconcile involvedness in living systems and may be defined simply as the engineering of biology; driven by technological advances in DNA synthesis, advances in computational methods, and the elucidation of complex heterologous synthesis of biomolecules [253]. Considering this, heterologous protein production in plants would open up for new technologies for developing an efficient and resourceful platform similar to the work on non proteineous biomolecules [254]. In this review, we highlighted the past attempts and recent progress in heterologous protein production in plants and its potential for commercial drug development and production. In conclusion, although plants as production platform face problems for public acceptance, undoubtedly it will definitely find its way into future as the best production platforms with constant support from the government, medical field, companies, and scientific community.

\section{Acknowledgements}

SBG would like to thank UM-DAE Centre for Excellence in Basic Sciences, Mumbai for constant support and encouragement and Department of Science and Technology (Govt. of India) for DST-INSPIRE Faculty award. VAB thanks National Academy of Sciences, India (NASI) for the honorary scientist fellowship.

\section{Conflict of Interest}

Authors declare that no conflict of interest exists.

\section{Ethical Statement}

Neither ethical approval nor informed consent was required for this study.

\section{References}

1. Mahmoud, K. (2007) Recombinant protein production: strategic technology and a vital research tool. Res. J. Cell. Mol. Biol. 1: 922.

2. Rai, M. and H. Padh (2001) Expression systems for production of heterologous proteins. Curr. Sci. 80: 1121-1128.

3. Chen, R., S. Yang, L. Zhang, and Y. J. Zhou (2020) Advanced 
strategies for production of natural products in yeast. iScience. 23: 100879.

4. Kutyna, D. R. and A. R. Borneman (2018) Heterologous production of flavour and aroma compounds in Saccharomyces cerevisiae. Genes. 9: 326.

5. Levisson, M., C. Araya-Cloutier, W. J. C. de Bruijn, M. van der Heide, J. M. S. Lopez, J. M. Daran, J. P. Vincken, and J. Beekwilder (2019) Toward developing a yeast cell factory for the production of prenylated flavonoids. J. Agric. Food Chem. $67: 13478-13486$.

6. Burnett, M. J. B. and A. C. Burnett (2019) Therapeutic recombinant protein production in plants: Challenges and opportunities. Plants People Planet. 2: 121-132.

7. Abd-Aziz, N., B. C. Tan, N. A. Rejab, R. Y. Othman, and N. Khalid (2020) A new plant expression system for producing pharmaceutical proteins. Mol. Biotechnol. 62: 240-251.

8. Schillberg, S., N. Raven, H. Spiegel, S. Rasche, and M. Buntru (2019) Critical analysis of the commercial potential of plants for the production of recombinant proteins. Front. Plant Sci. 10: 720.

9. Iyappan, G., R. O. Omosimua, and R. Sathishkumar (2019) Enhanced Production of therapeutic proteins in plants: Novel expression strategies. pp. 333-351. In: R. Sathishkumar, S. R. Kumar, J. Hema, and V. Baskar (eds.) Advances in Plant Transgenics: Methods and Applications. Springer, Singapore, Singapore.

10. Von Schaewen, A., I. S. Jeong, S. Rips, A. Fukudome, J. Tolley, Y. Nagashima, K. Fischer, H. Kaulfuerst-Soboll, and H. Koiwa (2018) Improved recombinant protein production in Arabidopsis thaliana. Plant Signal Behav. 13: e1486149.

11. Walsh, G. (2014) Biopharmaceutical benchmarks 2014. Nat. Biotechnol. 32: 992-1000.

12. Ritala, A., S. T. Häkkinen, and S. Schillberg (2014) Molecular pharming in plants and plant cell cultures: a great future ahead? Pharm. Bioprocess. 2: 223-226.

13. Itakura, K., T. Hirose, R. Crea, A. D. Riggs, H. L. Heyneker, F, Bolivar, and H. W. Boyer (1977) Expression in Escherichia coli of a chemically synthesized gene for the hormone somatostatin. Science. 198: 1056-1063.

14. Su, X., G. Schmitz, M. Zhang, R. I Mackie, and I. K. O. Cann (2012) Heterologous gene expression in filamentous fungi. $A d v$. Appl. Microbiol. 81: 1-61.

15. Nevalainen, H. and R. Peterson (2014) Making recombinant proteins in filamentous fungi- are we expecting too much? Front. Microbiol. 5: 75.

16. Sijmons, P. C., B. M. Dekker, B. Schrammeijer, T. C. Verwoerd, P. J. van den Elzen, and A. Hoekema (1990) Production of correctly processed human serum albumin in transgenic plants. Biotechnol. 8: 217-221.

17. Dyck, M. K., D. Lacroix, F. Pothier, and M. A. Sirard (2003) Making recombinant proteins in animals- different systems, different applications. Trends Biotechnol. 21: 394-399.

18. Wurm, F. M. (2004) Production of recombinant protein therapeutics in cultivated mammalian cells. Nat. Biotechnol. 22: 1393-1398.

19. Pillai, O. and R. Panchagnula (2001) Insulin therapies-past, present and future. Drug Discov. Today. 6: 1056-1061.

20. Hogue, R. S., J. M. Lee, and G. An (1990) Production of a foreign protein product with genetically modified plant cells. Enzyme Microb. Technol. 12: 533-538.

21. Nomura, T., S. Ogita, and Y. Kato (2018) Rational metabolicflow switching for the production of exogenous secondary metabolites in bamboo suspension cells. Sci. Rep. 8: 13203.

22. Khatodia, S. and S. M. P. Khurana (2018) Genetic engineering for plant transgenesis: Focus to pharmaceuticals. pp. 71-86. In: D. Barh and V. Azevedo (eds.) Omics Technologies and BioEngineering: Towards Improving Quality of Life. Academic
Press, London, UK.

23. Goulet, M. C., L. Gaudreau, M. Gagné, A. M. Maltais, A. C. Laliberté, G. Éthier, N. Bechtold, M. Martel, M. A. D'Aoust, A. Gosselin, S. Pepin, and D. Michaud (2019) Production of biopharmaceuticals in Nicotiana benthamiana-axillary stem growth as a key determinant of total protein yield. Front Plant Sci. 10: 735.

24. Séveno, M., M. Bardor, T. Paccalet, V. Gomord, P. Lerouge, and L. Faye (2004) Glycoprotein sialylation in plants? Nat. Biotechnol. 22: 1351-1352.

25. Strasser, R., F. Altmann, L. Mach, J. Glössl, and H. Steinkellner (2004) Generation of Arabidopsis thaliana plants with complex $\mathrm{N}$-glycans lacking $\beta 1,2$-linked xylose and core $\alpha 1,3$-linked fucose. FEBS Lett. 561: 132-136.

26. Daskalova, S. M., J. E. Radder, Z. A. Cichacz, S. H. Olsen, G. Tsaprailis, H. Mason, and L. C. Lopez (2010) Engineering of $N$. benthamiana $\mathrm{L}$. plants for production of $\mathrm{N}$-acetylgalactosamineglycosylated proteins-towards development of a plant-based platform for production of protein therapeutics with mucin type O-glycosylation. BMC Biotechnol. 10: 62.

27. Nagels, B., E. J. M. Van Damme, M. Pabst, N. Callewaert, and K. Weterings (2011) Production of complex multiantennary Nglycans in Nicotiana benthamiana plants. Plant Physiol. 155: 1103-1112.

28. Castilho, A., L. Neumann, S. Daskalova, H. S. Mason, H. Steinkellner, F. Altmann, and R. Strasser (2012) Engineering of sialylated mucin-type O-glycosylation in plants. J. Biol. Chem. 287: 36518-36526.

29. Strasser, R., F. Altmann, and H. Steinkellner (2014) Controlled glycosylation of plant-produced recombinant proteins. Curr. Opin. Biotechnol. 30: 95-100.

30. Cox, K. M., J. D. Sterling, J. T. Regan, J. R. Gasdaska, K. K. Frantz, C. G. Peele, A. Black, D. Passmore, C. MoldovanLoomis, M. Srinivasan, S. Cuison, P. M. Cardarelli, and L. F. Dickey (2006) Glycan optimization of a human monoclonal antibody in the aquatic plant Lemna minor. Nat. Biotechnol. 24: 1591-1597.

31. Ling, H. Y., A. Pelosi, and A. M. Walmsley (2010) Current status of plant-made vaccines for veterinary purposes. Expert Rev. Vaccines. 9: 971-982.

32. Yap, Y. K. And D. R. Smith (2010) Strategies for the plantbased expression of dengue subunit vaccines. Biotechnol Appl Biochem. 57: 47-53.

33. Sekellick, M. J., A. F. Ferrandino, D. A. Hopkins, and P. I. Marcus (1994) Chicken interferon gene: cloning, expression, and analysis. J. Interferon Res. 14: 71-79.

34. Digby, M. R. and J. W. Lowenthal (1995) Cloning and expression of the chicken interferon-gamma gene. J. Interferon Res. 15: 939-945.

35. Schultz, U., C. Rinderle, M. J. Sekellick, P. I. Marcus, and P. Staeheli (1995) Recombinant chicken interferon from Escherichia coli and transfected COS cells is biologically active. Eur. J. Biochem. 229: 73-76.

36. Arora, D. and N. Khanna (1996) Method for increasing the yield of properly folded recombinant human gamma interferon from inclusion bodies. J. Biotechnol. 52: 127-133.

37. Song, K. D., H. S. Lillehoj, K. D. Choi, D. Zarlenga, and J. Y. Han (1997) Expression and functional characterization of recombinant chicken interferon-gamma. Vet. Immunol. Immunopathol. 58: 321-333.

38. Argyle, D. J., M. Harris, C. Lawrence, K. McBride, R. Barron, C. McGillivray, and D. E. Onions (1998) Expression of feline recombinant interferon- $\gamma$ in baculovirus and demonstration of biological activity. Vet. Immunol. Immunopathol. 64: 97-105.

39. Yashiro, K., J. W. Lowenthal, T. E. O'Neil, S. Ebisu, H. Takagi, and R. J. Moore (2001) High-level production of recombinant 
chicken interferon- $\gamma$ by Brevibacillus choshinensis. Protein Expr. Purif. 23: 113-120.

40. Takehara, K., M. Kamikawa, N. Ohnuki, T. Nagata, A. Nakano, D. Yamaguchi, Y. Yokomizo, and M. Nakamura (2002) High level expression of C-terminal truncated recombinant chicken interferon- $\gamma$ in baculovirus vector system. J.Vet. Med. Sci. 2: 95100.

41. Wu, D., K. Murakami, N. Liu, Y. Inoshima, T. Yokoyama, T. Kokuho, S. Inumaru, T. Matsumura, T. Kondo, K. Nakano, and H. Sentsui (2002) Expression of biologically active recombinant equine interferon- $\gamma$ by two different baculovirus gene expression systems using insect cells and silkworm larvae. Cytokine. 2: 63-69.

42. Wu, Y. J., D. G. Zhao, L. Song, and W. Z. Xu (2008) Construction of plant expression vector consisting of ChIFN- $\gamma$ gene and its transient expression. J. Yunnan Univ. (Nat. Sci. Ed). 2008: 630-635.

43. Leelavathi, S. and V. S. Reddy (2003) Chloroplast expression of His-tagged GUS-fusions: a general strategy to overproduce and purify foreign proteins using transplastomic plants as bioreactors. Mol. Breed. 11: 49-58.

44. Chen, T. L., Y. L. Lin, Y. L. Lee, N. S. Yang, and M. T. Chan (2004) Expression of bioactive human interferon-gamma in transgenic rice cell suspension cultures. Transgenic Res. 13: 499-510.

45. Sun, Y. K., Y. F. Wang, H. D. Zhi, S. W. Liu, M. Wang, and G. Z. Tong (2005) Construction and characterization of a recombinant Fowlpox virus expressing chicken type II interferon. Chin. J. Agric. Biotechnol. 2: 143-148.

46. Balderas Hernández, V. E., L. M. T. Paz Maldonado, E. Medina Rivero, A. P. Barba de la Rosa, J. F. Jiménez-Bremont, L. G. Ordoñez Acevedo, and A. De León Rodríguez (2008) Periplasmic expression and recovery of human interferon gamma in Escherichia coli. Protein Expr. Purif. 59: 169-174.

47. Rupa, P., V. Monedero, and B. N. Wilkie (2008) Expression of bioactive porcine interferon-gamma by recombinant Lactococcus lactis. Vet. Microbiol. 129: 197-202.

48. Sareneva, T., K. Cantell, L. Pyhälä, J. Pirhonen, and I. Julkunen (1993) Effect of carbohydrates on the pharmacokinetics of human interferon- $\gamma$. J. Interferon Res. 13: 267-269.

49. Wu, Y., D. Zhao, L. Song, and W. Xu (2009) Heterologous expression of synthetic chicken IFN- $\gamma$ in transgenic tobacco plants. Biologia. 64: 1115-1122.

50. Soh, H. S., H. Y. Chung, H. H. Lee, H. Ajjappala, K. Jang, J. H. Park, J. S. Sim, G. Y. Lee, H. J. Lee, Y. H. Han, J. W. Lim, I. Choi, I. S. Chung, and B. S. Hahn (2015) Expression and functional validation of heat-labile enterotoxin B (LTB) and cholera toxin B (CTB) subunits in transgenic rice (Oryza sativa). SpringerPlus. 4: 148.

51. Gao, M., Y. Li, X. Xue, X. Wang, and J. Long (2012) Stable plastid transformation for high-level recombinant protein expression: promises and challenges. J. Biomed. Biotechnol. 2012: 158232.

52. Staub, J. M., B. Garcia, J. Graves, P. T. Hajdukiewicz, P. Hunter, N. Nehra, V. Paradkar, M. Schlittler, J. A. Carroll, L. Spatola, D. Ward, G. Ye, and D. A. Russell (2000) High-yield production of a human therapeutic protein in tobacco chloroplasts. Nat. Biotechnol. 18: 333-338.

53. Daniell, H., S. B. Lee, T. Panchal, and P. O. Wiebe (2001) Expression of the native cholera toxin B subunit gene and assembly as functional oligomers in transgenic tobacco chloroplasts. J. Mol. Biol. 311: 1001-1009.

54. Fernandez-San Millan, A., A. Mingo-Castel, M. Miller, and H. Daniell (2003) A chloroplast transgenic approach to hyperexpress and purify human serum albumin, a protein highly susceptible to proteolytic degradation. Plant Biotechnol. J. 1: 71-79.
55. Lee, S. B., H. B. Kwon, S. J. Kwon, S. C. Park, M. J. Jeong, S. E. Han, M. O. Byun, and H. Daniell (2003) Accumulation of trehalose within transgenic chloroplasts confers drought tolerance. Mol. Breed. 11: 1-13.

56. Koya, V., M. Moayeri, S. H. Leppla, and H. Daniell (2005) Plant-based vaccine: mice immunized with chloroplast-derived anthrax protective antigen survive anthrax lethal toxin challenge. Infect. Immun. 73: 8266-8274.

57. Oey, M., M. Lohse, B. Kreikemeyer, and R. Bock (2009) Exhaustion of the chloroplast protein synthesis capacity by massive expression of a highly stable protein antibiotic. Plant $J$. 57: 436-445.

58. De Cosa, B., W. Moar, S. B. Lee, M. Miller, and H. Daniell (2001) Overexpression of the Bt cry2Aa2 operon in chloroplasts leads to formation of insecticidal crystals. Nat. Biotechnol. 19: 71-74.

59. Jeong, S. W., W. J. Jeong, J. W. Woo, D. W. Choi, Y. I. Park, and J. R. Liu (2004) Dicistronic expression of the green fluorescent protein and antibiotic resistance genes in the plastid for selection and tracking of plastid-transformed cells in tobacco. Plant Cell Rep. 22: 747-751.

60. Maliga, P. (1993) Towards plastid transformation in flowering plants. Trends Biotechnol. 11: 101-107.

61. Daniell, H., M. S. Khan, and L. Allison (2002) Milestones in chloroplast genetic engineering: an environmentally friendly era in biotechnology. Trends Plant. Sci. 7: 84-91.

62. Ruhlman, T., D. Verma, N. Samson, and H. Daniell (2010) The role of heterologous chloroplast sequence elements in transgene integration and expression. Plant Physiol. 152: 2088-2104.

63. Bock, R. and M. S. Khan (2004) Taming plastids for a green future. Trends Biotechnol. 22: 311-318.

64. Daniell, H., S. Chebolu, S. Kumar, M. Singleton, and R. Falconer (2005) Chloroplast-derived vaccine antigens and other therapeutic proteins. Vaccine. 2: 1779-1783.

65. Singh, A. K., S. S. Verma, and K. C. Bansal (2010) Plastid transformation in eggplant (Solanum melongena L.). Transgenic Res. 19: 113-119.

66. Verma, D. and H. Daniell (2007) Chloroplast vector systems for biotechnology applications. Plant Physiol. 145: 1129-1143.

67. Fernández-San Millán, A., S. M. Ortigosa, S. Hervás-Stubbs, P. Corral-Martínez, J. M. Seguí-Simarro, J. Gaétan, P. Coursaget, and J. Veramendi (2008) Human papillomavirus L1 protein expressed in tobacco chloroplasts self-assembles into virus-like particles that are highly immunogenic. Plant Biotechnol. J. 6: 427-441.

68. Lenzi, P., N. Scotti, F. Alagna, M. L. Tornesello, A. Pompa, A. Vitale, A. De Stradis, L. Monti, S. Grillo, F. M. Buonaguro, P. Maliga, and T. Cardi (2008) Translational fusion of chloroplastexpressed human papillomavirus type $16 \mathrm{~L} 1$ capsid protein enhances antigen accumulation in transplastomic tobacco. Transgenic Res. 17: 1091-1102.

69. Madesis, P., M. Osathanunkul, U. Georgopoulou, M. F. Gisby, E. A. Mudd, I. Nianiou, P. Tsitoura, P. Mavromara, A. Tsaftaris, and A. Day (2010) A hepatitis C virus core polypeptide expressed in chloroplasts detects anti-core antibodies in infected human sera. J. Biotechnol. 145: 377-386.

70. Youm, J. W., J. H. Jeon, H. Kim, S. R. Min, M. S. Kim, H. Joung, W. J. Jeong, and H. S. Kim (2010) High-level expression of a human $\beta$-site APP cleaving enzyme in transgenic tobacco chloroplasts and its immunogenicity in mice. Transgenic Res. 19: 1099-1108.

71. Chen, Q., H. Lai, J. Hurtado, J. Stahnke, K. Leuzinger, and M. Dent (2013) Agroinfiltration as an effective and scalable strategy of gene delivery for production of pharmaceutical proteins. Adv. Tech. Biol. Med. 1: 103.

72. Leuzinger, K., M. Dent, J. Hurtado, J. Stahnke, H. Lai, X. Zhou, 
and Q. Chen (2013) Efficient agroinfiltration of plants for highlevel transient expression of recombinant proteins. J. Vis. Exp. 77: e50521.

73. Wagner, B., H. Fuchs, F. Adhami, Y. Ma, O. Scheiner, and H. Breiteneder (2004) Plant virus expression systems for transient production of recombinant allergens in Nicotiana benthamiana. Methods. 32: 227-234.

74. Lico, C., Q. Chen, and L. Santi (2008) Viral vectors for production of recombinant proteins in plants. J. Cell. Physiol. 216: 366-377.

75. Gleba, Y., V. Klimyuk, and S. Marillonnet (2005) Magnifectiona new platform for expressing recombinant vaccines in plants. Vaccine. 23: 2042-2048.

76. Carlsson, M. L. R., S. Kanagarajan, L. Bülow, and H. L. Zhu (2020) Plant based production of myoglobin - a novel source of the muscle heme-protein. Sci. Rep. 10: 920.

77. Pogue, G. P., J. A. Lindbo, S. J. Garger, and W. P. Fitzmaurice (2002) Making an ally from an enemy: plant virology and the new agriculture. Annu. Rev. Phytopathol. 40: 45-74.

78. Yusibov, V., S. J. Streatfield, and N. Kushnir (2011) Clinical development of plant-produced recombinant pharmaceuticals: vaccines, antibodies and beyond. Hum. Vaccin. 7: 313-321.

79. Gleba, Y., S. Marillonnet, and V. Klimyuk (2004) Engineering viral expression vectors for plants: the 'full virus' and the 'deconstructed virus' strategies. Curr. Opin. Plant Biol. 7: 182-188.

80. Fujiki, M., J. F. Kaczmarczyk, V. Yusibov, and S. Rabindran (2008) Development of a new cucumber mosaic virus-based plant expression vector with truncated 3 a movement protein. Virology. 381: 136-142.

81. Huang, Z., Q. Chen, B. Hjelm, C. Arntzen, and H. Mason (2009) A DNA replicon system for rapid high-level production of virus-like particles in plants. Biotechnol. Bioeng. 103: 706-714.

82. Plesha, M. A., T. K. Huang, A. M. Dandekar, B. W. Falk, and K. A. McDonald (2007) High-level transient production of a heterologous protein in plants by optimizing induction of a chemically inducible viral amplicon expression system. Biotechnol. Prog. 23: 1277-1285.

83. Musiychuk, K., N. Stephenson, H. Bi, C. E. Farrance, G. Orozovic, M. Brodelius, P. Brodelius, A. Horsey, N. Ugulava, A. M. Shamloul, V. Mett, S. Rabindran, S. J. Streatfield, and V. Yusibov (2007) A launch vector for the production of vaccine antigens in plants. Influenza Other Respir. Viruses. 1: 19-25.

84. Shoji, Y., H. Bi, K. Musiychuk, A. Rhee, A. Horsey, G. Roy, B. Green, M. Shamloul, C. E. Farrance, B. Taggart, N. Mytle, N. Ugulava, S. Rabindran, V. Mett, J. A. Chichester, and V. Yusibov (2009) Plant-derived hemagglutinin protects ferrets against challenge infection with the A/Indonesia/05/05 strain of avian influenza. Vaccine. 27: 1087-1092.

85. Marillonnet, S., A. Giritch, M. Gils, R. Kandzia, V. Klimyuk, and Y. Gleba (2004) In planta engineering of viral RNA replicons: efficient assembly by recombination of DNA modules delivered by Agrobacterium. Proc. Natl. Acad. Sci. USA. 101: 6852-6857.

86. Santi, L., A. Giritch, C. J. Roy, S. Marillonnet, V. Klimyuk, Y. Gleba, R. Webb, C. J. Arntzen, and H. S. Mason (2006) Protection conferred by recombinant Yersinia pestis antigens produced by a rapid and highly scalable plant expression system. Proc. Natl. Acad. Sci. USA. 103: 861-866.

87. Huang, Z., L. Santi, K. LePore, J. Kilbourne, C. J. Arntzen, and H. S. Mason (2006) Rapid, high-level production of hepatitis B core antigen in plant leaf and its immunogenicity in mice. Vaccine. 24: 2506-2513.

88. Santi, L., L. Batchelor, Z. Huang, B. Hjelm, J. Kilbourne, C. J. Arntzen, Q. Chen, and H. S. Mason (2008) An efficient plant viral expression system generating orally immunogenic Norwalk virus-like particles. Vaccine. 26: 1846-1854.
89. Qiu, X., G. Wong, J. Audet, A. Bello, L. Fernando, J. B. Alimonti, H. Fausther-Bovendo, H. Wei, J. Aviles, E. Hiatt, A. Johnson, J. Morton, K. Swope, O. Bohorov, N. Bohorova, C. Goodman, D. Kim, M. H. Pauly, J. Velasco, J. Pettitt, G. G. Olinger, K. Whaley, B. Xu, J. E. Strong, L. Zeitlin, and G. P. Kobinger (2014) Reversion of advanced Ebola virus disease in nonhuman primates with ZMapp. Nature. 514: 47-53.

90. Gils, M., R. Kandzia, S. Marillonnet, V. Klimyuk, and Y. Gleba (2005) High-yield production of authentic human growth hormone using a plant virus-based expression system. Plant Biotechnol. J. 3: 613-620.

91. Tregoning, J. S., P. Nixon, H. Kuroda, Z. Svab, S. Clare, F. Bowe, N. Fairweather, J. Ytterberg, K. J. van Wijk, G. Dougan, and P. Maliga (2003) Expression of tetanus toxin fragment $C$ in tobacco chloroplasts. Nucleic Acids Res. 31: 1174-1179.

92. Ruhlman, T., R. Ahangari, A. Devine, M. Samsam, and H. Daniell (2007) Expression of cholera toxin B-proinsulin fusion protein in lettuce and tobacco chloroplasts-oral administration protects against development of insulitis in non-obese diabetic mice. Plant Biotechnol. J. 5: 495-510.

93. Nityanandam, R. (2011) Expression and Functional Evaluation of Exendin 4 Fused to Cholera Toxin B Subunit in Tobacco Chloroplast to Treat Type 2 Diabetes. Master Thesis. University of Central Florida, Orlando, FL, USA.

94. Rosales-Mendoza, S., R. E. Soria-Guerra, R. López-Revilla, L. Moreno-Fierros, and A. G. Alpuche-Solís (2008) Ingestion of transgenic carrots expressing the Escherichia coli heat-labile enterotoxin B subunit protects mice against cholera toxin challenge. Plant Cell Rep. 27: 79-84.

95. Arlen, P. A., M. Singleton, J. J. Adamovicz, Y. Ding, A. Davoodi-Semiromi, and H. Daniell (2008) Effective plague vaccination via oral delivery of plant cells expressing F1-V antigens in chloroplasts. Infect. Immun. 76: 3640-3650.

96. Zhou, Y. X., M. Y. T. Lee, J. M. H. Ng, M. L. Chye, W. K. Yip, S. Y. Zee, and E. Lam (2006) A truncated hepatitis E virus ORF2 protein expressed in tobacco plastids is immunogenic in mice. World J. Gastroenterol. 12: 306-312.

97. Shao, H. B., D. M. He, K. X. Qian, G. F. Shen, and Z. L. Su (2008) The expression of classical swine fever virus structural protein E2 gene in tobacco chloroplasts for applying chloroplasts as bioreactors. C. R. Biol. 331: 179-184.

98. Chebolu, S. and H. Daniell (2007) Stable expression of Gal/ GalNAc lectin of Entamoeba histolytica in transgenic chloroplasts and immunogenicity in mice towards vaccine development for amoebiasis. Plant Biotechnol. J. 5: 230-239.

99. Davoodi-Semiromi, A., M. Schreiber, S. Nalapalli, D. Verma, N. D. Singh, R. K. Banks, D. Chakrabarti, and H. Daniell (2010) Chloroplast-derived vaccine antigens confer dual immunity against cholera and malaria by oral or injectable delivery. Plant Biotechnol. J. 8: 223-242.

100. Lakshmi, P. S., D. Verma, X. Yang, B. Lloyd, and H. Daniell (2013) Low cost tuberculosis vaccine antigens in capsules: expression in chloroplasts, bio-encapsulation, stability and functional evaluation in vitro. PLoS One. 8: e54708.

101. Lee, C., H. H. Kim, K. M. Choi, K. W. Chung, Y. K. Choi, M. J. Jang, T. S. Kim, N. J. Chung, H. G. Rhie, H. S. Lee, Y. Sohn, H. Kim, S. J. Lee, and H. W. Lee (2011) Murine immune responses to a Plasmodium vivax-derived chimeric recombinant protein expressed in Brassica napus. Malar. J. 10: 106.

102. Kapusta, J., A. Modelska, M. Figlerowicz, T. Pniewski, M. Letellier, O. Lisowa, V. Yusibov, H. Koprowski, A. Plucienniczak, and A. B. Legocki (1999) A plant-derived edible vaccine against hepatitis B virus. FASEB J. 13: 1796-1799.

103. Lai, H., J. He, M. Engle, M. S. Diamond, and Q. Chen (2012) Robust production of virus-like particles and monoclonal antibodies with geminiviral replicon vectors in lettuce. Plant 
Biotechnol. J. 10: 95-104.

104. Dong, J. L., B. G. Liang, Y. S. Jin, W. J. Zhang, and T. Wang (2005) Oral immunization with pBsVP6-transgenic alfalfa protects mice against rotavirus infection. Virology. 339: 153-163.

105. Wigdorovitz, A., C. Carrillo, M. J. Dus Santos, K. Trono, A. Peralta, M. C. Gómez, R. D. Ríos, P. M. Franzone, A. M. Sadir, J. M. Escribano, and M. V. Borca (1999) Induction of a protective antibody response to foot and mouth disease virus in mice following oral or parenteral immunization with alfalfa transgenic plants expressing the viral structural protein VP1. Virology. 255: 347-353.

106. Aguirreburualde, M. S. P., M. C. Gómez, A. Ostachuk, F. Wolman, G. Albanesi, A. Pecora, A. Odeon, F. Ardila, J. M. Escribano, M. J. Dus Santos, and A. Wigdorovitz (2013) Efficacy of a BVDV subunit vaccine produced in alfalfa transgenic plants. Vet. Immunol. Immunopathol. 151: 315-324.

107. Vianna, G., E. Rech, and N. da Cunha (2011) Expression and accumulation of heterologous molecules in the protein storage vacuoles of soybean seeds. Protoc. Exch. doi:10.1038/protex. 2011.206.

108. Hudson, L. C., K. L. Bost, and K. J. Piller (2011) Optimizing recombinant protein expression in soybean. pp. 19-42. In: A. Sudaric (ed.). Soybean - Molecular Aspects of Breeding. InTech Open, Rijeka, Croatia.

109. Oakes, J. L., K. L. Bost, and K. J. Piller (2009) Stability of a soybean seed-derived vaccine antigen following long-term storage, processing and transport in the absence of a cold chain. J. Sci. Food Agric. 89: 2191-2199.

110. Cunha, N. B., A. C. G. Araújo, A. Leite, A. M. Murad, G. R. Vianna, and E. L. Rech (2010) Correct targeting of proinsulin in protein storage vacuoles of transgenic soybean seeds. Genet. Mol. Res. 9: 1163-1170.

111. Moravec, T., M. A. Schmidt, E. M. Herman, and T. WoodfordThomas (2007) Production of Escherichia coli heat labile toxin (LT) B subunit in soybean seed and analysis of its immunogenicity as an oral vaccine. Vaccine. 25: 1647-1657.

112. De Jaeger, G., G. Angenon, and A. Depicker (2003) Exceptionally high heterologous protein levels in transgenic dicotyledonous seeds using Phaseolus vulgaris regulatory sequences. Commun. Agric. Appl. Biol. Sci. 68: 359-366.

113. De Jaeger, G., S. Scheffer, A. Jacobs, M. Zambre, O. Zobell, A. Goossens, A. Depicker, and G. Angenon (2002) Boosting heterologous protein production in transgenic dicotyledonous seeds using Phaseolus vulgaris regulatory sequences. Nat. Biotechnol. 20: 1265-1268.

114. Van Droogenbroeck, B., J. Cao, J. Stadlmann, F. Altmann, S. Colanesi, S. Hillmer, D. G. Robinson, E. Van Lerberge, N. Terryn, M. Van Montagu, M. Liang, A. Depicker, and G. De Jaeger (2007) Aberrant localization and underglycosylation of highly accumulating single-chain Fv-Fc antibodies in transgenic Arabidopsis seeds. Proc. Natl. Acad. Sci. USA. 104: 1430-1435.

115. Piron, R., S. De Koker, A. De Paepe, J. Goossens, J. Grooten, H. Nauwynck, and A. Depicker (2014) Boosting in planta production of antigens derived from the porcine reproductive and respiratory syndrome virus (PRRSV) and subsequent evaluation of their immunogenicity. PLoS One. 9: e91386.

116. He, X., J. D. Galpin, M. B. Tropak, D. Mahuran, T. Haselhorst, M. von Itzstein, D. Kolarich, N. H. Packer, Y. Miao, L. Jiang, G. A. Grabowski, L. A. Clarke, and A. R. Kermode (2012) Production of active human glucocerebrosidase in seeds of Arabidopsis thaliana complex-glycan-deficient (cgl) plants. Glycobiology. 22: 492-503.

117. Moeller, L., R. Taylor-Vokes, S. Fox, Q. Gan, L. Johnson, and K. Wang (2010) Wet-milling transgenic maize seed for fraction enrichment of recombinant subunit vaccine. Biotechnol. Prog. 26: 458-465.
118. Naqvi, S., K. Ramessar, G. Farré, M. Sabalza, B. Miralpeix, R. M. Twyman, T. Capell, C. Zhu, and P. Christou (2011) Highvalue products from transgenic maize. Biotechnol. Adv. 29: 40-53.

119. Streatfield, S. J., J. M. Mayor, D. K. Barker, C. Brooks, B. J. Lamphear, S. L. Woodard, K. K. Beifuss, D. V. Vicuna, L. A. Massey, M. E. Horn, D. E. Delaney, Z. L. Nikolov, E. E. Hood, J. M. Jilka, and J. A. Howard (2002) Development of an edible subunit vaccine in corn against enterotoxigenic strains of Escherichia coli. In Vitro Cell Dev. Biol. Plant. 38: 11-17.

120. Chikwamba, R., J. Cunnick, D. Hathaway, J. McMurray, H. Mason, and K. Wang (2002) A functional antigen in a practical crop: LT-B producing maize protects mice against Escherichia coli heat labile enterotoxin (LT) and cholera toxin (CT). Transgenic Res. 11: 479-493.

121. Lamphear, B. J., J. M. Jilka, L. Kesl, M. Welter, J. A. Howard, and S. J. Streatfield (2004) A corn-based delivery system for animal vaccines: an oral transmissible gastroenteritis virus vaccine boosts lactogenic immunity in swine. Vaccine. 22: 2420-2424.

122. Streatfield, S. J. (2005) Oral hepatitis B vaccine candidates produced and delivered in plant material. Immunol. Cell Biol. 83: 257-262.

123. Farinas, C. S., A. Leite, and E. A. Miranda (2007) Recombinant human proinsulin from transgenic corn endosperm: solvent screening and extraction studies. Braz. J. Chem. Eng. 24: 315323.

124. Karaman, S., J. Unnick, and K. Wang (2012) Expression of the cholera toxin B subunit (CT-B) in maize seeds and a combined mucosal treatment against cholera and traveler's diarrhea. Plant Cell Rep. 31: 527-537.

125. He, Y., T. Ning, T. Xie, Q. Qiu, L. Zhang, Y. Sun, D. Jiang, K. Fu, F. Yin, W. Zhang, L. Shen, H. Wang, J. Li, Q. Lin, Y. Sun, H. Li, Y. Zhu, and D. Yang (2011) Large-scale production of functional human serum albumin from transgenic rice seeds. Proc. Nat. Acad. Sci. USA. 108: 19078-19083.

126. Stoger, E., C. Vaquero, E. Torres, M. Sack, L. Nicholson, J. Drossard, S. Williams, D. Keen, Y. Perrin, P. Christou, and R. Fischer (2000) Cereal crops as viable production and storage systems for pharmaceutical ScFv antibodies. Plant. Mol. Biol. 42: 583-590.

127. Fujiwara, Y., Y. Aiki, L. Yang, F. Takaiwa, A. Kosaka, N. M. Tsuji, K. Shiraki, and K. Sekikawa (2010) Extraction and purification of human interleukin-10 from transgenic rice seeds. Protein Expr. Purif. 72: 125-130.

128. Takaiwa, F., L. Yang, H. Takagi, N. Maruyama, Y. Wakasa, K. Ozawa, and T. Hiroi (2019) Development of rice-seed-based oral allergy vaccines containing hypoallergenic Japanese cedar pollen allergen derivatives for immunotherapy. J. Agric. Food Chem. 67: 13127-13138.

129. Wakasa, Y., H. Takagi, N. Watanabe, N. Kitamura, Y. Fujiwara, Y. Ogo, S. Hayashi, L. Yang, M. Ohta, W. W. Thet Tin, K. Sekikawa, M. Takano, K. Ozawa, T. Hiroi, and F. Takaiwa (2015) Concentrated protein body product derived from rice endosperm as an oral tolerogen for allergen-specific immunotherapy-A new mucosal vaccine formulation against Japanese cedar pollen allergy. PLoS One. 10: e0120209.

130. Wakasa, Y., H. Takagi, S. Hirose, L. Yang, M. Saeki, T. Nishimura, O. Kaminuma, T. Hiroi, and F. Takaiwa (2013) Oral immunotherapy with transgenic rice seed containing destructed Japanese cedar pollen allergens, Cry j 1 and Cry j 2, against Japanese cedar pollinosis. Plant Biotechnol. J. 11: 66-76.

131. Hernández, A., A. López, Y. Ceballo, L. Rosabal, Y. Rosabal, K. Tiel, M. Pérez, E. M. González, O. Ramos, and G. Enríquez (2013) High-level production and aggregation of hepatitis B surface antigen in transgenic tobacco seeds. Biotecnol. Apl. 30: 97-100. 
132. Mohammadzadeh, S., F. Roohvand, S. Ajdary, P. Ehsani, and A. Hatef Salmanian (2015) Heterologous expression of hepatitis C virus core protein in oil seeds of Brassica napus L. Jundishapur J. Microbiol. 8: e25462.

133. Yang, L., Y. Tada, M. P. Yamamoto, H. Zhao, M. Yoshikawa, and F. Takaiwa (2006) A transgenic rice seed accumulating an anti-hypertensive peptide reduces the blood pressure of spontaneously hypertensive rats. FEBS Lett. 580: 3315-3320.

134. Alvarez, M. L., H. L. Pinyerd, J. D. Crisantes, M. M. Rigano, J. Pinkhasov, A. M. Walmsley, H. S. Mason, and G. A. Cardineau (2006) Plant-made subunit vaccine against pneumonic and bubonic plague is orally immunogenic in mice. Vaccine. 24 : 2477-2490.

135. Soria-Guerra, R. E., S. Rosales-Mendoza, C. MárquezMercado, R. López-Revilla, R. Castillo-Collazo, and A. G. Alpuche-Solís (2007) Transgenic tomatoes express an antigenic polypeptide containing epitopes of the diphtheria, pertussis and tetanus exotoxins, encoded by a synthetic gene. Plant Cell Rep. 26: 961-968.

136. Loc, N. H., D. T. Long, T. G. Kim, and M. S. Yang (2014) Expression of Escherichia coli heat-labile enterotoxin B subunit in transgenic tomato (Solanum lycopersicum L.) fruit. Czech J. Genet. Plant Breed. 50: 26-31.

137. McGarvey, P. B., J. Hammond, M. M. Dienelt, D. C. Hooper, Z. F. Fu, B. Dietzschold, H. Koprowski, and F. H. Michaels (1995) Expression of the rabies virus glycoprotein in transgenic tomatoes. Biotechnology (N Y). 13: 1484-1487.

138. Sandhu, J. S., S. F. Krasnyanski, L. L. Domier, S. S. Korban, M. D. Osadjan, and D. E. Buetow (2000) Oral immunization of mice with transgenic tomato fruit expressing respiratory syncytial virus-F protein induces a systemic immune response. Transgenic Res. 9: 127-135.

139. Ma, Y., S. Q. Lin, Y. Gao, M. Li, W. X. Luo, J. Zhang, and N. S. Xia (2003) Expression of ORF2 partial gene of hepatitis E virus in tomatoes and immunoactivity of expression products. World J. Gastroenterol. 9: 2211-2215.

140. Saldaña, S., F. Esquivel Guadarrama, J. Olivera-Flores Tde, N. Arias, S. López, C. Arias, R. Ruiz-Medrano, H. Mason, T. Mor, L. Richter, C. J. Arntzen, and M. A. Gómez Lim (2006) Production of rotavirus-like particles in tomato (Lycopersicon esculentum L.) fruit by expression of capsid proteins VP2 and VP6 and immunological studies. Viral Immunol. 19: 42-53.

141. Shchelkunov, S. N., R. K. Salyaev, S. G. Pozdnyakov, N. I. Rekoslavskaya, A. E. Nesterov, T. S. Ryzhova, V. M. Sumtsova, N. V. Pakova, U. O. Mishutina, T. V. Kopytina, and R. W. Hammond (2006) Immunogenicity of a novel, bivalent, plantbased oral vaccine against hepatitis B and human immunodeficiency viruses. Biotechnol. Lett. 28: 959-967.

142. Zhang, X., N. A. Buehner, A. M. Hutson, M. K. Estes, and H. S. Mason (2006) Tomato is a highly effective vehicle for expression and oral immunization with Norwalk virus capsid protein. Plant Biotechnol. J. 4: 419-432.

143. Lou, X. M., Q. H. Yao, Z. Zhang, R. H. Peng, A. S. Xiong, and H. K. Wang (2007) Expression of the human hepatitis B virus large surface antigen gene in transgenic tomato plants. Clin. Vaccine Immunol. 14: 464-469.

144. Paz de la Rosa, G., A. Monroy-García, M. de L. Mora-García, C. G. R. Peña, J. Hernández-Montes, B. Weiss-Steider, and M. A. Gómez-Lim (2009) An HPV 16 L1-based chimeric human papilloma virus-like particles containing a string of epitopes produced in plants is able to elicit humoral and cytotoxic T-cell activity in mice. Virol. J. 6: 2.

145. Hirai, T., Y. W. Kim, K. Kato, K. Hiwasa-Tanase, and H. Ezura (2011) Uniform accumulation of recombinant miraculin protein in transgenic tomato fruit using a fruit-ripening-specific E8 promoter. Transgenic Res. 20: 1285-1292.
146. Kumar, G. B., T. R. Ganapathi, C. J. Revathi, L. Srinivas, and V. A. Bapat (2005) Expression of hepatitis B surface antigen in transgenic banana plants. Planta. 222: 484-493.

147. Renuga, G., R. Saravanan, A. Babu Thandapani, and K. R. Arumugam (2010) Expression of Cholera toxin B subunit in Banana callus culture. J. Pharm. Sci. Res. 2: 26-33.

148. Rybicki, E. P. (2009) Third international conference on plantbased vaccines and antibodies. Expert. Rev. Vaccines. 8: 11511155 .

149. Tabayashi, N. and T. Matsumura (2014) Forefront study of plant biotechnology for practical use: development of oral drug for animal derived from transgenic strawberry. Soc. Biotechnol. J. Japan. 92: 537-539.

150. Hiwasa-Tanase, K. and H. Ezura (2016) Molecular breeding to create optimized crops: from genetic manipulation to potential applications in plant factories. Front. Plant Sci. 7: 539.

151. Thanavala, Y., M. Mahoney, S. Pal, A. Scott, L. Richter, N. Natarajan, P. Goodwin, C. J. Arntzen, and H. S. Mason (2005) Immunogenicity in humans of an edible vaccine for hepatitis B. Proc. Natl. Acad. Sci. USA. 102: 3378-3382.

152. Kim, T. W., Y. M. Goo, C. H. Lee, B. H. Lee, J. M. Bae, and S. W. Lee (2009) The sweet potato ADP-glucose pyrophosphorylase gene (ibAGP1) promoter confers high-level expression of the GUS reporter gene in the potato tuber. C. R. Biol. 332: 876-885.

153. Mason, H. S., T. A. Haq, J. D. Clements, and C. J. Arntzen (1998) Edible vaccine protects mice against Escherichia coli heat-labile enterotoxin (LT): potatoes expressing a synthetic LTB gene. Vaccine. 16: 1336-1343.

154. Arakawa, T., D. K. Chong, and W. H. Langridge (1998) Efficacy of a food plant-based oral cholera toxin B subunit vaccine. Nat. Biotechnol. 16: 292-297.

155. Arakawa, T., J. Yu, D. K. Chong, J. Hough, P. C. Engen, and W. H. Langridge (1998) A plant-based cholera toxin B subunitinsulin fusion protein protects against the development of autoimmune diabetes. Nat. Biotechnol. 16: 934-938.

156. Kong, Q., L. Richter, Y. F. Yang, C. J. Arntzen, H. S. Mason, and Y. Thanavala (2001) Oral immunization with hepatitis B surface antigen expressed in transgenic plants. Proc. Natl. Acad. Sci. USA. 98: 11539-11544.

157. Ohya, K., T. Matsumura, K. Ohashi, M. Onuma, and C. Sugimoto (2001) Expression of two subtypes of human IFNalpha in transgenic potato plants. J. Interferon Cytokine Res. 21: 595-602.

158. Fukuzawa, N., N. Tabayashi, Y. Okinaka, R. Furusawa, K. Furuta, U. Kagaya, and T. Matsumura (2010) Production of biologically active Atlantic salmon interferon in transgenic potato and rice plants. J. Biosci. Bioeng. 110: 201-207.

159. Tacket, C. O., H. S. Mason, G. Losonsky, M. K. Estes, M. M. Levine, and C. J. Arntzen (2000) Human immune responses to a novel Norwalk virus vaccine delivered in transgenic potatoes. $J$. Infect. Dis. 182: 302-305.

160. Kim, Y. S., T. J. Kang, Y. S. Jang, and M. S. Yang (2005) Expression of neutralizing epitope of porcine epidemic diarrhea virus in potato plants. Plant Cell Tiss. Organ. Cult. 82: 125-130.

161. Chen, X. and J. Liu (2011) Generation and immunogenicity of transgenic potato expressing the GP5 protein of porcine reproductive and respiratory syndrome virus. J. Virol. Methods. 173: 153-158.

162. Wu, Y. Z., J. T. Li, Z. R. Mou, L. Fei, B. Ni, M. Geng, Z. C. Jia, W. Zhou, L. Y. Zou, and Y. Tang (2003) Oral immunization with rotavirus VP7 expressed in transgenic potatoes induced high titers of mucosal neutralizing IgA. Virology. 313: 337-342.

163. Zhou, J. Y., J. X. Wu, L. Q. Cheng, X. J. Zheng, H. Gong, S. B. Shang, and E. M. Zhou (2003) Expression of immunogenic S1 glycoprotein of infectious bronchitis virus in transgenic potatoes. J. Virol. 77: 9090-9093. 
164. Warzecha, H., H. S. Mason, C. Lane, A. Tryggvesson, E. Rybicki, A. L. Williamson, J. D. Clements, and R. C. Rose (2003) Oral immunogenicity of human papillomavirus-like particles expressed in potato. J. Virol. 77: 8702-8711.

165. Biemelt, S., U. Sonnewald, P. Galmbacher, L. Willmitzer, and M. Müller (2003) Production of human papillomavirus type 16 virus-like particles in transgenic plants. J. Virol. 77: 9211-9220.

166. Bř́za, J., D. Pavingerova, J. Vlasak, V. Ludikova, and H. Niedermeierova (2007) Production of human papillomavirus type $16 \mathrm{E} 7$ oncoprotein fused with $\beta$-glucuronidase in transgenic tomato and potato plants. Biol. Plant. 51: 268.

167. Yu, J. And W. H. Langridge (2001) A plant-based multicomponent vaccine protects mice from enteric diseases. Nat. Biotechnol. 19: $548-552$

168. Tremblay, R., M. Feng, R. Menassa, N. P. A. Huner, A. M. Jevnikar, and S. Ma (2011) High-yield expression of recombinant soybean agglutinin in plants using transient and stable systems. Transgenic Res. 20: 345-356.

169. Chong, D. K., W. Roberts, T. Arakawa, K. Illes, G. Bagi, C. W. Slattery, and W. H. Langridge (1997) Expression of the human milk protein beta-casein in transgenic potato plants. Trangenic Res. 6: 289-296.

170. Chong, D. K. and W. H. Langridge (2000) Expression of fulllength bioactive antimicrobial human lactoferrin in potato plants. Transgenic Res. 9: 71-78.

171. Carter, J. E., O. Odumosu, and W. H. R. Langridge (2010) Expression of a ricin toxin $\mathrm{B}$ subunit: insulin fusion protein in edible plant tissues. Mol. Biotechnol. 44: 90-100.

172. Chakraborty, S., N. Chakraborty, and A. Datta (2000) Increased nutritive value of transgenic potato by expressing a nonallergenic seed albumin gene from Amaranthus hypochondriacus. Proc. Natl. Acad. Sci. USA. 97: 3724-3729.

173. Permyakova, N. V., A. A. Zagorskaya, P. A. Belavin, E. A. Uvarova, O. V. Nosareva, A. E. Nesterov, A. A. Novikovskaya, E. L. Zav'yalov, M. P. Moshkin, and E. V. Deineko (2015) Transgenic carrot expressing fusion protein comprising $M$. tuberculosis antigens induces immune response in mice. Biomed. Res. Int. 2015: 417565.

174. Rosales-Mendoza, S., R. E. Soria-Guerra, L. Moreno-Fierros, Y. Han, Á. G. Alpuche-Solís, and S. S. Korban (2011) Transgenic carrot tap roots expressing an immunogenic F1-V fusion protein from Yersinia pestis are immunogenic in mice. $J$. Plant Physiol. 168: 174-180.

175. Woods, R. R., B. C. Geyer, and T. S. Mor (2008) Hairy-root organ cultures for the production of human acetylcholinesterase. BMC Biotechnol. 8: 95.

176. Aleinein, R. A., H. Schafer, and M. Wink (2015) Rhizosecretion of the recombinant antimicrobial peptide ranalexin from transgenic tobacco hairy roots. RRJBS. S1: 45-55.

177. Lonoce, C., C. Marusic, E. Morrocchi, A. M. Salzano, A. Scaloni, F. Novelli, C. Pioli, M. Feeney, L. Frigerio, and M. Donini (2019) Enhancing the secretion of a glyco-engineered anti-CD20 scFv-Fc antibody in hairy root cultures. Biotechnol. J. 14: e1800081.

178. Gurusamy, P. D., H. Schafer, S. Ramamoorthy, and W. Wink (2017) Biologically active recombinant human erythropoietin expressed in hairy root cultures and regenerated plantlets of Nicotiana tabacum L. PLoS One. 12: e0182367.

179. Liu, C., M. J. Towler, G. Medrano, C. L. Cramer, and P. J. Weathers (2009) Production of mouse interleukin-12 is greater in tobacco hairy roots grown in a mist reactor than in an airlift reactor. Biotechnol. Bioeng. 102: 1074-1086.

180. López, E. G., E. G. R. Ramírez, O. G. Gúzman, G. C. Calva, A. Ariza-Castolo, J. Pérez-Vargas, and H. G. M. Rodríguez (2014) MALDI-TOF characterization of hGH1 produced by hairy root cultures of Brassica oleracea var. italica grown in an airlift with mesh bioreactor. Biotechnol. Prog. 30: 161-171.

181. Cardon, F., R. Pallisse, M. Bardor, A. Caron, J. Vanier, J. P. Ele Ekouna, P. Lerouge, M. Boitel-Conti, and M. Guillet (2019) Brassica rapa hairy root based expression system leads to the production of highly homogenous and reproducible profiles of recombinant human alpha-L-iduronidase. Plant Biotechnol. J. 17: 505-516.

182. Dutt, M., S. A. Dhekney, L. Soriano, R. Kandel, and J. W. Grosser (2014) Temporal and spatial control of gene expression in horticultural crops. Hortic. Res. 1: 14047.

183. Stefanov, I., S. Illubaev, A. Feher, K. Margoczi, and D. Dudits (1991) Promoter and genotype dependent transient expression of a reporter gene in plant protoplasts. Acta Biol. Hung. 42: 323330.

184. Herman, S. R., R. M. Harding, and J. L. Dale (2001) The banana actin 1 promoter drives near-constitutive transgene expression in vegetative tissues of banana (Musa spp.). Plant Cell Rep. 20: 525-530.

185. Menassa, R., H. Zhu, C. N. Karatzas, A. Lazaris, A. Richman, and J. Brandle (2004) Spider dragline silk proteins in transgenic tobacco leaves: accumulation and field production. Plant Biotechnol. J. 2: 431-438.

186. Rancé, I., F. Norre, V. Gruber, and M. Theisen (2002) Combination of viral promoter sequences to generate highly active promoters for heterologous therapeutic protein overexpression in plants. Plant Sci. 162: 833-842.

187. Duan, Z., K. Ito, and M. Tominaga (2020) Heterologous transformation of Camelina sativa with high-speed chimeric myosin XI-2 promotes plant growth and leads to increased seed yield. Plant Biotechnol. 37: 253-259.

188. Kinkema, M., R. J. Geijskes, K. Shand, H. D. Coleman, P. C. De Lucca, A. Palupe, M. D. Harrison, I. Jepson, J. L. Dale, and M. B. Sainz (2014) An improved chemically inducible gene switch that functions in the monocotyledonous plant sugar cane. Plant Mol. Biol. 84: 443-454.

189. Dugdale, B., C. L. Mortimer, M. Kato, T. A. James, R. M. Harding, and J. L. Dale (2013) In Plant Activation: An inducible, hyperexpression platform for recombinant protein production in plants. Plant Cell. 25: 2429-2443.

190. Hood, E. E., D. R. Witcher, S. Maddock, T. Meyer, C. Baszczynski, M. Bailey, P. Flynn, J. Register, L. Marshall, D. Bond, E. Kulisek, A. Kusnadi, R. Evangelista, Z. Nikolov, C. Wooge, R. J. Mehigh, R. Hernan, W. K. Kappel, D. Ritland, C. P. Li, and J. A. Howard (1997) Commercial production of avidin from transgenic maize: characterization of transformant, production, processing, extraction and purification. Mol. Breed. 3: 291-306.

191. Nagaya, S., K. Kawamura, A. Shinmyo, and K. Kato (2010) The HSP terminator of Arabidopsis thaliana increases gene expression in plant cells. Plant Cell Physiol. 51: 328-332.

192. Limkul, J., R. Misaki, K. Kato, and K. Fujiyama (2015) The combination of plant translational enhancers and terminator increase the expression of human glucocerebrosidase in Nicotiana benthamiana plants. Plant Sci. 240: 41-49.

193. Bourdon, V., A. Harvey, and D. M. Lonsdale (2001) Introns and their positions affect the translational activity of mRNA in plant cells. EMBO Rep. 2: 394-398.

194. Morello, L. and D. Breviario (2008) Plant spliceosomal introns: not only cut and paste. Curr. Genomics. 9: 227-238.

195. Vitale, A. and J. Denecke (1999) The endoplasmic reticulumgateway of the secretory pathway. Plant Cell. 11: 615-628.

196. De Meyer, T. and A. Depicker (2014) Trafficking of endoplasmic reticulum-retained recombinant proteins is unpredictable in Arabidopsis thaliana. Front. Plant Sci. 5: 473.

197. Fischer, R., D. Schumann, S. Zimmermann, J. Drossard, M. Sack, and S. Schillberg (1999) Expression and characterization 
of bispecific single-chain $\mathrm{Fv}_{\mathrm{V}}$ fragments produced in transgenic plants. Eur. J. Biochem. 262: 810-816.

198. Outchkourov, N. S., B. Rogelj, B. Strukelj, and M. A. Jongsma (2003) Expression of sea anemone equistatin in potato. Effects of plant proteases on heterologous protein production. Plant Physiol. 133: 379-390.

199. Benchabane, M., C. Goulet, D. Rivard, L. Faye, V. Gomord, and D. Michaud (2008) Preventing unintended proteolysis in plant protein biofactories. Plant Biotechnol. J. 6: 633-648.

200. Kim, T. G., H. J. Lee, Y. S. Jang, Y. J. Shin, T. H. Kwon, and M. S. Yang (2008) Co-expression of proteinase inhibitor enhances recombinant human granulocyte-macrophage colony stimulating factor production in transgenic rice cell suspension culture. Protein Expr. Purif. 61: 117-121.

201. Sainsbury, F., M. Benchabane, M. C. Goulet, and D. Michaud (2012) Multimodal protein constructs for herbivore insect control. Toxins. 4: 455-475.

202. Pillay, P., U. Schlüter, S. van Wyk, K. J. Kunert, and B. J. Vorster (2014) Proteolysis of recombinant proteins in bioengineered plant cells. Bioengineered. 5: 15-20.

203. Hellwig, S., J. Drossard, R. M. Twyman, and R. Fischer (2004) Plant cell cultures for the production of recombinant proteins. Nat. Biotechnol. 22: 1415-1422.

204. Huang, T. K. and K. A. McDonald (2012) Bioreactor systems for in vitro production of foreign proteins using plant cell cultures. Biotechnol. Adv. 30: 398-409.

205. Lee, S. Y., W. Hur, G. H. Cho, and D. I. Kim (2001) Cultivation of transgenic Nicotiana tabacum suspension cells in bioreactors for the production of mGM-CSF. Biotechnol. Bioprocess Eng. 6: $72-74$

206. Tekoah, Y., A. Shulman, T. Kizhner, I. Ruderfer, L. Fux, Y. Nataf, D. Bartfeld, T. Ariel, S. Gingis-Velitski, U. Hanania, and Y. Shaaltiel (2015) Large-scale production of pharmaceutical proteins in plant cell culture-the protalix experience. Plant Biotechnol. J. 13: 1199-1208.

207. Rosales-Mendoza, S. and M. A. Tello-Olea (2015) Carrot cells: a pioneering platform for biopharmaceuticals production. Mol. Biotechnol. 57: 219-232.

208. Lee, S. J., C. I. Park, M. Y. Park, H. S. Jung, W. S. Ryu, S. M. Lim, H. K. Tan, T. H. Kwon, M. S. Yang, and D. I. Kim (2007) Production and characterization of human CTLA4Ig expressed in transgenic rice cell suspension cultures. Protein Expr. Purif. 51: 293-302.

209. Liu, Y. K., L. F. Huang, S. L. Ho, C. Y. Liao, H. Y. Liu, Y. H. Lai, S. M. Yu, and C. A. Lu (2012) Production of mouse granulocyte-macrophage colony-stimulating factor by gateway technology and transgenic rice cell culture. Biotechnol. Bioeng. 109: 1239-1247.

210. Su, C. F., I. C. Kuo, P. W. Chen, C. H. Huang, S. V. Seow, K. Y. Chua, and S. M. Yu (2012) Characterization of an immunomodulatory Der $\mathrm{p}$ 2-FIP-fve fusion protein produced in transformed rice suspension cell culture. Transgenic Res. 21: 177-192.

211. McDonald, K. A., L. M. Hong, D. M. Trombly, Q. Xie, and A. P. Jackman (2005) Production of human alpha-1-antitrypsin from transgenic rice cell culture in a membrane bioreactor. Biotechnol. Prog. 21: 728-734.

212. Kim, T. G., M. Y. Baek, E. K. Lee, T. H. Kwon, and M. S. Yang (2008) Expression of human growth hormone in transgenic rice cell suspension culture. Plant Cell Rep. 27: 885-891.

213. Decker, E. L., J. Parsons, and R. Reski (2014) Glyco-engineering for biopharmaceutical production in moss bioreactors. Front. Plant Sci. 5: 346.

214. Reski, R., J. Parsons, and E. L. Decker (2015) Moss-made pharmaceuticals: from bench to bedside. Plant Biotechnol. J. 13: 1191-1198.
215. Baur, A., R. Reski, and G. Gorr (2005) Enhanced recovery of a secreted recombinant human growth factor using stabilizing additives and by co-expression of human serum albumin in the moss Physcomitrella patens. Plant Biotechnol. J. 3: 331-340.

216. Weise, A., F. Altmann, M. Rodriguez-Franco, E. R. Sjoberg, W. Bäumer, H. Launhardt, M. Kietzmann, and G. Gorr (2007) High-level expression of secreted complex glycosylated recombinant human erythropoietin in the Physcomitrella $\Delta$-fuct $\Delta$-xyl-t mutant. Plant Biotechnol. J. 5: 389-401.

217. Büttner-Mainik, A., J. Parsons, H. Jérôme, A. Hartmann, S. Lamer, A. Schaaf, A. Schlosser, P. F. Zipfel, R. Reski, and E. L. Decker (2011) Production of biologically active recombinant human factor H in Physcomitrella. Plant Biotechnol. J. 9: 373383.

218. Orellana-Escobedo, L., S. Rosales-Mendoza, A. RomeroMaldonado, J. Parsons, E. L. Decker, E. Monreal-Escalante, L. Moreno-Fierros, and R. Reski (2015) An Env-derived multiepitope HIV chimeric protein produced in the moss Physcomitrella patens is immunogenic in mice. Plant Cell Rep. 34: 425-433.

219. Kircheis, R., N. Halanek, I. Koller, W. Jost, M. Schuster, G. Gorr, K. Hajszan, and A. Nechansky (2012) Correlation of ADCC activity with cytokine release induced by the stably expressed, glyco-engineered humanized Lewis Y-specific monoclonal antibody MB314. MAbs. 4: 532-541.

220. Niederkrüger, H., P. Dabrowska-Schlepp, and A. Schaaf (2014) Suspension culture of plant cells under phototrophic conditions. pp. 259-292. In : H. P. Meyer and D. R. Schmidhalter (eds.). Industrial Scale Suspension Culture of Living Cells. WileyVCH Verlag GmbH \& Co. KGaA, Weinheim, Germany.

221. Strasser, R., A. Castilho, J. Stadlmann, R. Kunert, H. Quendler, P. Gattinger, J. Jez, T. Rademacher, F. Altmann, L. Mach, and H. Steinkellner (2009) Improved virus neutralization by plantproduced anti-HIV antibodies with a homogeneous $\beta 1,4-$ galactosylated N-glycan profile. J. Biol. Chem. 284: 2047920485.

222. Arcalis, E., J. Stadlmann, T. Rademacher, S. Marcel, M. Sack, F. Altmann, and E. Stoger (2013) Plant species and organ influence the structure and subcellular localization of recombinant glycoproteins. Plant Mol. Biol. 83: 105-117.

223. Diamos, A. G., J. G. L. Hunter, M. D. Pardhe, S. H. Rosenthal, H. Sun, B. C. Foster, M. P. DiPalma, Q. Chen, and H. S. Mason (2020) High level production of monoclonal antibodies using an optimized plant expression system. Front Bioeng. Biotechnol. 7: 472.

224. Ma, J. K., B. Y. Hikmat, K. Wycoff, N. D. Vine, D. Chargelegue, L. Yu, M. B. Hein, and T. Lehner (1998) Characterization of a recombinant plant monoclonal secretory antibody and preventive immunotherapy in humans. Nat. Med. 4: 601-606.

225. Rosenberg, Y., M. Sack, D. Montefiori, D. Forthal, L. Mao, S. Hernandez-Abanto, L. Urban, G. Landucci, R. Fischer, and X. Jiang (2013) Rapid high-level production of functional HIV broadly neutralizing monoclonal antibodies in transient plant expression systems. PLoS One. 8: e58724.

226. Ma, J. K., J. Drossard, D. Lewis, F. Altmann, J. Boyle, P. Christou, T. Cole, P. Dale, C. J. van Dolleweerd, V. Isitt, D. Katinger, M. Lobedan, H. Mertens, M. J. Paul, T. Rademacher, M. Sack, P. A. C. Hundleby, G. Stiegler, E. Stoger, R. M. Twyman, B. Vcelar, and R. Fischer (2015) Regulatory approval and a first-in-human phase I clinical trial of a monoclonal antibody produced in transgenic tobacco plants. Plant Biotechnol. J. 13: 1106-1120.

227. Pujol, M., N. I. Ramírez, M. Ayala, J. V. Gavilondo, R. Valdés, M. Rodríguez, J. Brito, S. Padilla, L. Gómez, B. Reyes, R. Peral, M. Pérez, J. L. Marcelo, L. Milá, R. F. Sánchez, R. Páez, J. A. Cremata, G. Enríquez, O. Mendoza, M. Ortega, and C. 
Borroto (2005) An integral approach towards a practical application for a plant-made monoclonal antibody in vaccine purification. Vaccine. 23: 1833-1837.

228. Rybicki, E. P. (2010) Plant-made vaccines for humans and animals. Plant Biotechnol. J. 8: 620-637.

229. Tacket, C. O., H. S. Mason, G. Losonsky, J. D. Clements, M. M. Levine, and C. J. Arntzen (1998) Immunogenicity in humans of a recombinant bacterial antigen delivered in a transgenic potato. Nat. Med. 4: 607-609.

230. Tacket, C. O., M. F. Pasetti, R. Edelman, J. A. Howard, and S. Streatfield (2004) Immunogenicity of recombinant LT-B delivered orally to humans in transgenic corn. Vaccine. 22: 4385-4389.

231. Fischer, R., S. Schillberg, S. Hellwig, R. M. Twyman, and J. Drossard (2012) GMP issues for recombinant plant-derived pharmaceutical proteins. Biotechnol. Adv. 30: 434-439.

232. Dietzschold, B., M. Gore, D. Marchadier, H. S. Niu, H. M. Bunschoten, L. Otvos Jr, W. H. Wunner, H. C. Ertl, A. D. Osterhaus, and H. Koprowski (1990) Structural and immunological characterization of a linear virus-neutralizing epitope of the rabies virus glycoprotein and its possible use in a synthetic vaccine. J. Virol. 64: 3804-3809.

233. Modelska, A., B. Dietzschold, N. Sleysh, Z. F. Fu, K. Steplewski, D. C. Hooper, H. Koprowski, and V. Yusibov (1998) Immunization against rabies with plant-derived antigen. Proc. Natl. Acad. Sci. USA. 95: 2481-2485.

234. Yusibov, V., D. C. Hooper, S. V. Spitsin, N. Fleysh, R. B. Kean, T. Mikheeva, D. Deka, A. Karasev, S. Cox, J. Randall, and H. Koprowski (2002) Expression in plants and immunogenicity of plant virus-based experimental rabies vaccine. Vaccine. 20: 3155-3164.

235. D’Aoust, M. A., P. O. Lavoie, M. M. J. Couture, S. Trépanier, J. M. Guay, M. Dargis, S. Mongrand, N. Landry, B. J. Ward, and L. P. Vézina (2008) Influenza virus-like particles produced by transient expression in Nicotiana benthamiana induce a protective immune response against a lethal viral challenge in mice. Plant Biotechnol. J. 6: 930-940.

236. Landry, N., B. J. Ward, S. Trépanier, E. Montomoli, M. Dargis, G. Lapini, and L. P. Vézina (2010) Preclinical and clinical development of plant-made virus-like particle vaccine against avian H5N1 influenza. PLoS One. 5: e15559.

237. Landry, N., S. Pillet, D. Favre, J. F. Poulin, S. Trépanier, B. Yassine-Diab, and B. J. Ward (2014) Influenza virus-like particle vaccines made in Nicotiana benthamiana elicit durable, poly-functional and cross-reactive $\mathrm{T}$ cell responses to influenza HA antigens. Clin. Immunol. 154: 164-177.

238. Ward, B. J., N. Landry, S. Trépanier, G. Mercier, M. Dargis, M. Couture, M. A. D'Aoust, and L. P. Vézina (2014) Human antibody response to $\mathrm{N}$-glycans present on plant-made influenza virus-like particle (VLP) vaccines. Vaccine. 32: 6098-6106.

239. Shoji, Y., J. A. Chichester, M. Jones, S. D. Manceva, E. Damon, V. Mett, K. Musiychuk, H. Bi, C. Farrance, M. Shamloul, N. Kushnir, S. Sharma, and V. Yusibov (2011) Plant-based rapid production of recombinant subunit hemagglutinin vaccines targeting H1N1 and H5N1 influenza. Human Vaccin. 7 suppl: 41-50.

240. Shoji, Y., A. Prokhnevsky, B. Leffet, N. Vetter, S. Tottey, S. Satinover, K. Musiychuk, M. Shamloul, J. Norikane, R. M. Jones, J. A. Chichester, B. J. Green, S. J. Streatfield, and V. Yusibov (2015) Immunogenicity of H1N1 influenza virus-like particles produced in Nicotiana benthamiana. Human Vaccin Immunother. 11: 118-123.

241. Chichester, J. A., R. M. Jones, B. J. Green, M. Stow, F. Miao, G. Moonsammy, S. J. Streatfield, and V. Yusibov (2012) Safety and immunogenicity of a plant-produced recombinant hemagglutininbased influenza vaccine (HAI-05) derived from A/Indonesia/
05/2005 (H5N1) influenza virus: a phase 1 randomized, doubleblind, placebo-controlled, dose-escalation study in healthy adults. Viruses. 4: 3227-3244.

242. Cummings, J. F., M. L. Guerrero, J. E. Moon, P. Waterman, R. K. Nielsen, S. Jefferson, F. L. Gross, K. Hancock, J. M. Katz, V. Yusibov, and Fraunhofer USA Center for Molecular Biotechnology Study Group (2014) Safety and immunogenicity of a plantproduced recombinant monomer hemagglutinin-based influenza vaccine derived from influenza A (H1N1) pdm09 virus: a Phase 1 dose-escalation study in healthy adults. Vaccine. 32: 2251-2259.

243. Jones, R. M., J. A. Chichester, V. Mett, J. Jaje, S. Tottey, S. Manceva, L. J. Casta, S. K. Gibbs, K. Musiychuk, M. Shamloul, J. Norikane, V. Mett, S. J. Streatfield, M. van de Vegte-Bolmer, W. Roeffen, R. W. Sauerwein, and V. Yusibov (2013) A plantproduced Pfs 25 VLP malaria vaccine candidate induces persistent transmission blocking antibodies against Plasmodium falciparum in immunized mice. PLoS One. 8:e79538.

244. Rattanapisit, K., B. Shanmugaraj, S. Manopwisedjaroen, P. B. Purwono, K. Siriwattananon, N. Khorattanakulchai, O. Hanittinan, W. Boonyayothin, A. Thitithanyanont, D. R. Smith, and W. Phoolcharoen (2020) Rapid production of SARS-CoV-2 receptor binding domain (RBD) and spike specific monoclonal antibody CR3022 in Nicotiana benthamiana. Sci. Rep. 10: 17698.

245. Shaaltiel, Y., D. Bartfeld, S. Hashmueli, G. Baum, E. BrillAlmon, G. Galili, O. Dym, S. A. Boldin-Adamsky, I. Silman, J. L. Sussman, A. H. Futerman, and D. Aviezer (2007) Production of glucocerebrosidase with terminal mannose glycans for enzyme replacement therapy of Gaucher's disease using a plant cell system. Plant Biotechnol. J. 5: 579-590.

246. Molony, M. M., J. Boothe, R. Keon, C. Nykiforuk, and G. van Rooijen (2009) Methods for the production of insulin in plants. US Patent 7,547,821 B2.

247. Samyn-Petit, B., V. Gruber, C. Flahaut, J. P. Wajda-Dubos, S. Farrer, A. Pons, G. Desmaizieres, M. C. Slomianny, M. Theisen, and P. Delannoy (2001) N-glycosylation potential of maize: The human lactoferrin used as a model. Glycoconj J. 18: 519-527.

248. Humphrey, B. D., N. Haung, and K. Klasing (2002) Rice expressing lactoferrin and lysozyme has antibiotic-like properties when fed to chicks. J. Nutr. 132: 1214-1218.

249. Hennegan, K., D. Yang, D. Nguyen, L. Wu, J. Goding, J. Huang, F. Guo, N. Huang, and S. C. Watkins (2005) Improvement of human lysozyme expression in transgenic rice grain by combining wheat (Triticum aestivum) puroindoline $\mathrm{b}$ and rice (Oryza sativa) Gt1 promoters and signal peptides. Transgenic Res. 14: 583-592.

250. Mulvaney, D. R., T. Krupnik, and K. B. Koffler (2011) Transgenic rice evaluated for risks to marketability. Calif. Agric. 65: 161-167.

251. Fedosov, S. N., N. B. Laursen, E. Nexø, S. K. Moestrup, T. E. Petersen, E. Ø. Jensen, and L. Berglund (2003) Human intrinsic factor expressed in the plant Arabidopsis thaliana. Eur. J. Biochem. 270: 3362-3367.

252. Menassa, R., C. Du, Z. Q. Yin, S. Ma, P. Poussier, J. Brandle, and A. M. Jevnikar (2007) Therapeutic effectiveness of orally administered transgenic low-alkaloid tobacco expressing human interleukin-10 in a mouse model of colitis. Plant Biotechnol. J. 5: 50-59.

253. Walker, R. S. K. and I. S. Pretorius (2018) Applications of yeast synthetic biology geared towards the production of biopharmaceuticals. Genes. 9: 340.

254. Marchev, A. S., Z. P. Yordanova, and M. I. Georgiev (2020) Green (cell) factories for advanced production of plant secondary metabolites. Crit. Rev. Biotechnol. 40: 443-458.

Publisher's Note Springer Nature remains neutral with regard to jurisdictional claims in published maps and institutional affiliations. 